Dissolved $\mathrm{Cd}, \mathrm{Co}, \mathrm{Cu}, \mathrm{Fe}, \mathrm{Mn}, \mathrm{Ni}$ and $\mathrm{Zn}$ in the Arctic Ocean

Gerringa, L.J.A. ${ }^{1}$, Rijkenberg, M.J.A. ${ }^{1}$, Slagter, H.A. ${ }^{1,2}$, Laan, P. ${ }^{1}$, Paffrath, R. ${ }^{3}$, Bauch, D. ${ }^{4}$, Rutgers van der Loeff, M. ${ }^{5}$, Middag, R. $^{1}$

1. Royal Netherlands Institute for Sea Research (NIOZ), Department of Ocean Systems, Texel, the Netherlands.

2. Max Planck Institute for Chemistry, Mainz, Germany

3. Marine Isotope Geochemistry, Institute for Chemistry and Biology of the Marine Environment (ICBM), University of Oldenburg, Oldenburg, Germany

4. Leibniz Laboratory for Radiometric Dating and Stable Isotope Research, Kiel University, Kiel, Germany and GEOMAR Helmholtz Centre for Ocean Research, Kiel, Germany

5. Alfred Wegener Institute, Helmholtz Centre for Polar and Marine Research, Bremerhaven, Germany

This article has been accepted for publication and undergone full peer review but has not been through the copyediting, typesetting, pagination and proofreading process, which may lead to differences between this version and the Version of Record. Please cite this article as doi: 10.1029/2021JC017323. 
Key points:

- The transpolar drift is one of the major transport mechanisms of silicate, dissolved $\mathrm{Cu}, \mathrm{Fe}, \mathrm{Mn}$ and $\mathrm{Ni}$ into and through the Arctic Ocean

- In the Makarov Basin, Pacific waters are a source of dissolved cadmium, copper, manganese and nickel, but not of iron

- The longer residence time of waters in the Makarov basin result in a decrease of dissolved metal concentrations

This article is protected by copyright. All rights reserved. 
Abstract

During the Polarstern (PS94) expedition, summer 2015, part of the international GEOTRACES program, sources and sinks of dissolved (D) $\mathrm{Cd}, \mathrm{Co}, \mathrm{Cu}, \mathrm{Fe}, \mathrm{Mn}, \mathrm{Ni}$ and $\mathrm{Zn}$ were studied in the central Arctic Ocean. In the Polar Surface Water in which the TransPolar Drift (TPD) is situated, salinity and $\delta^{18} \mathrm{O}$ derived fractions indicated a distinct riverine source for silicate DCo, DCu, DFe, DMn and DNi. Linear relationships between DMn and the meteoric fraction depended on source distance, likely due to Mn-precipitation during transport. In the upper $50 \mathrm{~m}$ of the Makarov Basin, outside the TPD core, DCo, DMn, DNi, DCd and DCu were enriched by Pacific waters, whereas DFe seemed diluted. DCo, DFe, DMn and DZn were relatively high in the Barents Sea and led to enrichment of Atlantic water flowing into the Nansen Basin. Deep concentrations of all metals were significantly lower in the Makarov Basin compared to the Nansen and Amundsen, the Eurasian, Basins. The Gakkel ridge hydrothermal input and higher continental slope convection are explanations for higher metal concentrations in the Eurasian Basins. Although scavenging rates are lower in the Makarov Basin compared to the Eurasian Basins, the residence time is longer and therefore scavenging can decrease the dissolved concentrations with time. This study provides a baseline to assess future change, and additionally identifies processes driving trace metal distributions. Our results underline the importance of fluvial input as well as shelf sources and internal cycling, notably scavenging, for the distribution of bio-active metals in the Arctic Ocean.

\section{Abstract in Plain language}

Of the oceans on our planet, the Arctic Ocean is subject to the most rapid climate change. The temperature rise, increases the discharge of Arctic river water, rich in nutrients, dissolved metals and organic matter. The transpolar drift (TPD), transports this water over the Arctic Ocean towards the Atlantic Ocean.

In the present study we describe the dissolved concentrations of biologically active trace metals cadmium, cobalt, copper, iron, manganese, nickel and zinc in the central Arctic Ocean during an expedition with the ice breaker Polarstern.

Our results showed that rivers bring iron, cobalt, copper, iron, manganese, nickel into the Arctic Ocean, transported further by the TPD. In the deep waters, deeper than 1500-2000 $\mathrm{m}$, there is a significant difference in the concentrations of all metals between the Eurasian and the American-Canadian side of the Artic Ocean, where all metals have higher concentrations on the Eurasian side. This is explained by a combination of input from 
underwater volcanos, input from the shelves at the Eurasian side and the longer residence time in the American-Canadian deep water. Stripping of metals by sinking particles in the American-Canadian deep water can be more effective due to the longer residence time.

\section{Introduction}

The Arctic Ocean is subject to more rapid climate change compared to other oceans (IPCC, 2014; Serreze et al., 2016; Serreze and Stroeve, 2015; Maslanik et al., 2011; Dickson et al., 2008). The decreasing sea-ice cover increases light penetration which has a strong influence on primary production (Arrigo and van Dijken, 2011, 2015; Arrigo et al., 2008, 2012; Lowry et al., 2018; Lewis et al., 2018). Additionally, the rise in temperature increases shelf inputs (Rutgers van der Loeff et al., 2018; Kipp et al. 2018) and discharge with associated nutrient input of Arctic river water from snow and ice melt as well as permafrost thawing. The Arctic Ocean is exceptional in having a high surface area of adjacent shelf seas at the Eurasian side being the Barents Sea, the Kara Sea and the Laptev Sea (Figure 1A) and a large river influence with the major rivers being the $\mathrm{Ob}$, Yenisei and Lena (Raiswell and Anderson, 2005; Stedmon, et al., 2011; Rudels, 2012). The fresh water input together with sea ice melt makes the Polar Surface Water (PSW) relatively fresh. In the PSW the Transpolar Drift (TPD) moves sea ice and river water from the Siberian shelf seas to Fram Strait (Gordienko and Laktionov, 1969; Gregor et al., 1998; Rudels, 2015). The dominant surface current transports river water containing nutrients, metals and humic matter trough the Arctic Ocean in the direction of Fram Strait. The PSW is separated via a strong halocline from the underlying Atlantic Water (AW), which is transformed into Atlantic Arctic Water (AAW) during transport along the shelves through the Arctic Ocean (Figure 1A, 2A, B, Rudels, 1986; 2009; Aagaard and Carmack, 1989; water masses are defined in section 2.5 Water mass distinction). The inflow of AW through the Barents Sea and through the Fram Strait introduces warm and saline water into the Arctic Ocean via a counter clockwise circulation, and this inflow plays an important role in the thermohaline circulation of the Arctic and global oceans (Anderson et al., 1994; Rudels et al., 2000; Hansen et al., 2008) (Figure 1A). The inflow of heat by the AW is increasing, influencing not only the Atlantic layer but also weakening the stratification of the halocline, leading to enhanced sea-ice loss (Carmack et al., 2015, 2016; Polyakov et al., 2017). The deep Arctic Ocean, containing the Intermediate Water (IW) and Polar Deep Water (PDW) masses is divided by oceanic ridges, more or less separating the PDW into basins (Figure 1B, 2A). From the Eurasian to the AmericanCanadian continent, the Gakkel Ridge with its many deep passages and hydrothermal

This article is protected by copyright. All rights reserved. 
hotspots, forms the boundary between the two Eurasian Basins: the Nansen and Amundsen Basins whereas the Lomonosov ridge forms the boundary between the Amundsen and Makarov Basins. The latter ridge also separates the Eurasian Basins from the Amerasian Basins. The Makarov Basin is separated from the Canada Basin by the Alpha Ridge and the Mendeleev Ridge. The deep water in the Makarov Basin is older, warmer and saltier than in the Eurasian Basins due to dense water formation and hardly any exchange occurs between the deep Makarov and other basins and oceans, whereas for the Eurasian Basins exchange occurs through the Norwegian Sea and Fram Strait with fresher and colder Greenland Deep Sea Water (Aagaard,1980; Aagaard et al., 1985; Rudels 1986; Rudels, 2015).

Climate change induced modifications are also observed in deeper water masses than the PSW (Karcher et al., 2010). This is reflected in the Atlantic water (AAW) and Intermediate waters (IW) in the distribution ${ }^{230} \mathrm{Th}$ (Valk et al., 2020, Grenier et al., 2019). Other anthropogenic influences are shown by the penetration of ${ }^{129} \mathrm{I},{ }^{236} \mathrm{U}$ in the AAW (Casacuberta et al., 2016, 2018) and CFC and SF6 in intermediate and deep waters (Tanhua et al, 2009, Smethie, 2017: doi:10.1594/PANGAEA.872956). The climate induced changes not only influence temperature, salinity and penetration of isotopes and pollutants, but also the biogeochemical cycles of bio-active metals $\mathrm{Co}, \mathrm{Cu}, \mathrm{Fe}, \mathrm{Mn}, \mathrm{Ni}$ and $\mathrm{Zn}$, which are essential trace metals necessary for growth of phytoplankton, the base of the marine food web. In the surface open ocean, the dissolved concentrations of these trace metals are generally low due to biological uptake (Bruland et al., 2014; De Baar and La Roche, 2003: Sunda, 2012). With increasing depth, concentrations increase due to release via bacterial decomposition of organic matter, thus creating a so-called nutrient type depth profile, unless other processes besides regeneration play a role, like scavenging for $\mathrm{Mn}$ that usually displays a scavenged type depth profile. Dissolved Cd also shows a nutrient type depth profile, however, $\mathrm{Cd}$ is currently not considered to be an essential nutrient, even though for some diatom species it can replace $\mathrm{Zn}$ in carbonic anhydrase and some species even have $\mathrm{Cd}$ specific carbonic anhydrase enzymes (Price and Morel, 1990; Lane and Morel, 2000; Xu et al., 2008; Lane, 2005).

Because of the changes occurring in the Arctic Ocean, such as changing river input and melting sea ice, it is essential to study the sources and sinks of bio-active metals in order to understand the current system and assess ongoing changes. Sources of dissolved metals to the ocean are atmospheric deposition, river input, sea ice melt, melting ice bergs, decomposition of (sinking) organic material, lateral transport of releases over the shelf, input from the sediment by diagenesis and via resuspension and hydrothermal input, whereas sinks are 
formed by uptake of organisms, predominantly in the photic zone, as well as coagulation, precipitation and scavenging followed by settling of particles out of the water column (Middag et al., 2011;Klunder et al., 2012a,b; Bullard et al., 2017; Rijkenberg et al., 2018; Whitmore et al., 2019; Zhang et al., 2019; Jensen et al., 2019, 2020). Increased temperatures, increase phytoplankton growth and consequently the consumption of macro nutrients and bioactive trace metals increase too (Arrigo et al., 2008, Arrigo and van Dijken 2015; Rijkenberg et al., 2018). Depending on light availability, a new steady state will develop and the consumption will likely increase until one nutrient will become limiting. More research is necessary to anticipate on these dynamic processes, it might be a macro-nutrient but outside the TPD flow path it might also be DFe that becomes limiting (Arrigo and van Dijken, 2011; Lowry et al., 2018; Rijkenberg et al., 2018).

The influence of dust is estimated to be of minor importance in the Arctic Ocean (Bullard et al., 2017), especially in comparison to other surface sources. In the flow path of the TPD or in regions with ice melt or lateral fluxes from the shelves, the surface concentrations of the bioactive metals in the Arctic Ocean can be relatively high in contrast to other open oceans (Middag et al., 2011, Klunder et al., 2012a, Slagter et al., 2017; Rijkenberg et al., 2018; Jensen et al., 1919, 2020; Charette et al., 2020). Specifically, high input from melting sea ice occurs from so called dirty sea ice or anchor ice, sediment laden sea ice from the shallow parts of the shelf seas (Measures, 1999; Ito et al.,2019; Darby et al., 2011).

Besides dirty sea ice, river water contains large amounts of humic material, which can bind or chelate trace metals, especially $\mathrm{Fe}$, but also $\mathrm{Mn}, \mathrm{Zn}, \mathrm{Cu}, \mathrm{Co}, \mathrm{Ni}$ and $\mathrm{Cd}$ that are known to bind to dissolved organic ligands. Humic material flocculates and sinks out of the water column to a significant degree in estuaries (Yang et al., 2017), but the fraction of humics that reaches the ocean, increases the solubility and thus the residence time of trace metals as predominantly studied for $\mathrm{Fe}$ and $\mathrm{Cu}$ (Sholkovitz and Copland, 1981; Laglera and van den Berg., 2009; Laglera et al., 2019;; Whitby and van den Berg, 2015; Yang et al., 2017; Slagter et al., 2019, Sukekava et al., 2018). Although this is in general known for the exchange between rivers and oceans, there is substantial variation between different river systems and preciously little is known about the distribution of riverine metal input in the Arctic Ocean. The distribution of river water in the Arctic Ocean has been studied extensively (Ekwurzel et al., 2001, Carmack et al., 2015; Laukert et al., 2017; Ditmar and Kattner, 2003) and also the trace metals content of Eurasian rivers and the distribution in estuaries and nearby shelves has been investigated, from the nineteen nineties onwards (Guieu, et al. 1996; Dai and Martin, 1995; Martin et al., 1993; Garnier et al., 1996; Gordeev, 2000; Guay et al, 2010). The

This article is protected by copyright. All rights reserved. 
dissolved concentrations of $\mathrm{Fe}$ and $\mathrm{Mn}$ of the rivers are considerably higher, 4 to 20 times, than the shelf water, most likely due to coagulation and loss from the dissolved phase (Guieu et al., 1996 in the Lena River and estuary in 1991; Höleman et al., 2005 in the Lena river and estuary 1996), whereas DCd, DCu and DNi increase 1.5 to 6 fold during transport into the estuary, most likely due to mobilization from a particulate fraction. Also DZn has been reported to increase from the river into the shelf sea due to mixing with the higher DZn in seawater (Jensen et al., 2019). However, the transport and distribution of trace metals beyond the shallow shelf seas into the Arctic Ocean have long not been studied after the pioneer work done on single stations (Yeats and Westerlund, 1991; Moore, 1981). Since sampling equipment has been improved over time enabling sampling of more stations, as far as we know Klunder et al (2012 a,b) and Middag et al. (2011) are the only studies on the distribution and processes affecting trace metals in the Eurasian part of the Arctic Ocean before results of our present cruise were published (Charette et al., 2020; Rijkenberg et al., 2018; Slagter et al., 2017,2019). Moreover, the above publications by Klunder and Middag are restricted to results from one cruise and about two trace metals, Fe and Mn, whereas, this study adds insights for other metals as well.

The deep waters of the Nansen Basin have higher dissolved metal concentrations than in the deep Makarov Basin for some metals like DFe and DMn, whereas the Makarov Basin has higher phosphate and silicate concentrations (Jones et al., 2003; Middag et al., 2011; Klunder et al., 2012b; Rijkenberg et al., 2018). Grenier et al., (2019) concluded that in the Makarov and Canada Basins, scavenging has become more important since 2000, especially in coastal areas, probably due to increased primary productivity (Arrigo et al., 2008; Arrigo and van Dijken, 2015) and sediment resuspension. The intensification of scavenging is not limited to the coastal environment, Valk et al. (2020) argued that an increased scavenging in waters flowing into the Eurasian basin through the Barents Sea affected intermediate depth waters in the Amundsen Basin and Grenier at al. (2019) suggested that increased lateral exchange increased scavenging as well. Gdaniec et al. (2020) compared the Nansen, Amundsen and Makarov Basins and showed that compared to the Makarov Basin, the Amundsen and Nansen Basins were much more subjected to boundary scavenging. Near the ocean margins or boundaries, scavenging is more intense due to higher particle densities by resuspension processes, and this is thus called boundary scavenging (Anderson et al., 1983; Lao et al., 1992; Roy-Barman, 2009). Klunder et al. (2012b) and Middag et al. (2011) could distinguish DFe and DMn input from re-suspension of sediments from the shelf slopes into 
the Nansen Basin, the Basin with most terrestrial influence, however as far as we know no other trace metal data is available.

In summer 2015, the international Pan-Arctic GEOTRACES program set out three separate expeditions to sample the Arctic Ocean for organic and inorganic carbon, nutrients, trace metals and isotopes. In the present study we describe the dissolved concentrations of biological active trace metals in the central Arctic Ocean during the TRANSARCII Polarstern (PS94) expedition in summer 2015 (GN04). We show and discuss the river input and distribution in the TPD of dissolved $\mathrm{Cd}, \mathrm{Co}, \mathrm{Cu}, \mathrm{Fe}, \mathrm{Mn}, \mathrm{Ni}$ and $\mathrm{Zn}$. We describe the differences in the surface layer between the open ocean in the Nansen Basins and the ice covered Amundsen and Makarov basins, that are influenced by the TPD. We show that not only DFe has higher concentrations in the deep Eurasian basins compared to the Makarov Basin but also DCo, DCu, DNi and DZn and discuss whether shelf processes and residence time of the deep water offer probable explanations. Moreover, we connect our results with those from the GEOTRACES GN01 cruise executed simultaneously in the Canadian Basins (Jensen et al., 2019, 2020, Charette et al., 2020; Bundy et al., 2020). Since the DFe data obtained by ship board Flow Injection Analysis (FIA) was published previously (Rijkenberg et al., 2018), as was the dissolved organic speciation of DFe (Slagter et al., 2017, 2019; Laglera et al., 2019) the focus here is on the other six metals DCd, DCo, DCu, DMn, DNi and DZn.

\section{Methods and equipment}

\subsection{Sampling}

During the GEOTRACES TransARC II cruise (PS94) on the German icebreaker RV Polarstern, 28 stations were sampled between 17 August and 14 October 2015 (Figure 1A,B). Samples for trace metal analysis were taken using 24 trace-metal clean polypropylene samplers of $24 \mathrm{~L}$, each mounted on an all titanium frame with a SEABIRD 911 CTD system(de Baar et al., 2008; Rijkenberg et al., 2015, stations sampled with this CTD are given in Figure 1A). The frame was deployed on a $11 \mathrm{~mm}$ Dyneema cable without internal signal transduction cables and an SBE 17plus V2 Searam in a titanium housing provided power, saved the CTD data and closed the sampling bottles at pre-programmed depths. After deployment, the complete sampling system was pushed into an ISO Class 6 clean room container. Here samples for dissolved metals were filtered directly from the polypropylene samplers over $<0.2 \mu \mathrm{m}$ Sartobran 300 cartridges (Sartorius) under mild pressure ( 0.7 bar) of filtered $\mathrm{N}_{2}$ applied via the top-connector of the polypropylene sampler. The filters were rinsed

This article is protected by copyright. All rights reserved. 
with approximately $700 \mathrm{~mL}$ seawater before use. Samples for dissolved metals were acidified to a $\mathrm{pH}$ of 1.8 at a final concentration of $0.024 \mathrm{M}$ ultraclean Seastar Base-line $\mathrm{HCl}$ (Seastar Chemicals).

Samples for stable oxygen isotope analysis of the water $\left(\delta^{18} \mathrm{O}\right)$ were taken from a standard rosette in $50 \mathrm{~mL}$ glass bottles (Stations sampled with the standard rosette are shown in Figure 1B).

\subsection{Trace metal analysis}

Trace metals $\mathrm{Cd}, \mathrm{Co}, \mathrm{Cu}, \mathrm{Fe}, \mathrm{Mn}, \mathrm{Ni}$ and $\mathrm{Zn}$ were analysed with a Thermo Finnigan HR-ICPMS element 2 after pre-concentration and matrix removal. A volume of $30 \mathrm{~mL}$ sample was pipetted into an acid cleaned FEP vial. An internal standard (lutetium and indium) was added at a final concentration of $5 \mathrm{nM}$ prior to UV digestion (Middag et al., 2015). The samples were digested for $4 \mathrm{~h}$ in a home-made UV box after which they were pre-concentrated with by factor of 40 using a seaFAST offline pre-concentration system, using Nobias PA1 resin as a pre-concentration column (Lagerstrom et al., 2013; Bown et al., 2017; Gerringa et al., 2020). Samples were eluted in $1.5 \mathrm{M}$ teflon distilled $\mathrm{HNO}_{3}$ that contained rhodium as a standard to easily identify any sample introduction issues in a run whereas the indium and lutetium were used as the internal standards in the quantification (Middag et al., 2015).

The system was calibrated with seven standard additions using a home-made stock solution. The maximum standard additions were comparable to maximum concentrations in the marine environment. The recovery was verified in every analytical run by comparing the slope of the seawater calibration curve (multi-element standard added to seawater) and an eluent calibration curve (multi-element standard added directly to the elution acid) after Biller and Bruland (2012). Blank contributions from the sample handling, pre-concentration and analyses steps were determined by treating analysing acidified MQ water $(\sim 1.8 \mathrm{pH})$ as a sample. The accuracy and precision of the measurements were determined by measuring standard reference samples (GSP and SAFeD1) and in-house reference water (North Atlantic deep water (1000 m, 39.7 N, 14.2 E) (Table 1a,b) and via GEOTRACES intercalibration exercises. The detection limit was estimated as 3 times the standard deviation of the blank except for $\mathrm{Cd}$. The $\mathrm{MoO}$ interference correction required in the determination of $\mathrm{Cd}$ is especially important at low concentration and cannot be ignored as is implicitly done when using a milliQ sample that does not contain Mo (Biller and Bruland, 2012). The Cd detection limit was estimated as 3 times the standard deviation of the laboratory Surface Seawater standard (SSW). The standard deviation for all samples was calculated following

This article is protected by copyright. All rights reserved. 
Seyitmuhammedov et al. (2020) as the square root of the sum of the internal and external standard deviations $(\mathrm{SD}), S D=\sqrt{S{D_{I N T}}^{2}+S D_{E X T}^{2}}$.

The internal SD (SDINT) being the SD of the ICP-MS measurement, and the external SD (SDEXT) the SD of the specific element of the in house reference water measured regularly during the time of measuring the whole dataset $(\mathrm{N}=18)$.

Data on trace metals can be found at https://doi.org/10.1594/PANGAEA.932797 (under review) and https://dataportal.nioz.nl/doi/10.25850/nioz/7b.b.jc.

\subsection{Nutrient Analysis}

Nutrients were sampled from both the trace metal clean and standard rosette (Figure 1B). Phosphate, silicate, nitrite and nitrate were analyzed in unfiltered samples immediately after sampling in a temperature controlled laboratory container with a Technicon TRAACS 800 continuous flow auto analyser (Murphy and Riley, 1962; Strickland and Parsons, 1972; Grasshoff,1983). Details on the method, precision and detection limits are described by Rijkenberg et al. (2018). Data on nutrients can be found at https://doi.org/10.1594/PANGAEA.868396

\section{$2.4 \delta^{18} \mathrm{O}$ and nutrient based water mass fractions}

Stable isotope analyses were made at CEOAS (College of Earth, Ocean, and Atmospheric Science, Oregon State University, Oregon; details given in Paffrath et al., 2021). A water mass analysis for marine water, meteoric or river water and sea-ice meltwater may be based on $\mathrm{S} / \delta^{18} \mathrm{O}$ mass balances (Bauch et al, 2011, 1995). Salinity and $\delta^{18} \mathrm{O}$ show a first order linear correlation due to the mixture of marine water $\left(\sim 0 \%\right.$ in $\left.\delta^{18} \mathrm{O}\right)$ with significant amounts of isotopically depleted meteoric water. Meteoric water consists of river runoff and local precipitation, with similar isotopic composition due to their common source. The deviations from the linear correlation between salinity and $\delta^{18} \mathrm{O}$ are caused by sea-ice processes. In the southern Eurasian Basin marine waters solely consist of Atlantic-derived waters and water masses may be separated by simple 3-component mass balance calculations (Östlund and Hut, 1984). The marine source in the northern and eastern Eurasian Basin as well as in the North American basins (Makarov and Canadian basins) is expected to be a mixture of Atlantic and Pacific-derived waters (Bauch et al., 1995; Jones et al., 2008; Yamamoto-Kawai et al., 2008) and a 4-component mass balance has to be applied. In this study, a 4-component N/P-based mass balance is applied. The mass balance is further governed by the following equations:

This article is protected by copyright. All rights reserved. 


$$
\begin{aligned}
& f_{a}+f_{p}+f_{S I M}+f_{M W}=1 \\
& f_{a} S_{a}+f_{p} S_{p}+f_{S I M} S_{S I M}+f_{M W} S_{M W}=S_{\text {meas }} \\
& f_{a} O_{a}+f_{p} O_{p}+f_{S I M} O_{S I M}+f_{M W} O_{M W}=O_{\text {meas }} \\
& f_{a} P_{a}+f_{p} P_{p}+f_{S I M} P_{S I M}+f_{M W} P_{M W}=P_{\text {meas }}
\end{aligned}
$$

where $f_{a}$ is the fraction of Atlantic water, $f_{p}$ the fraction of Pacific-derived water, $f_{S I M}$ the fraction of sea-ice meltwater, and $\mathrm{f}_{\mathrm{MW}}$ is the fraction of meteoric water. $\mathrm{S}, \mathrm{O}$ and $\mathrm{P}$ with the corresponding subscript are the endmember values and measured values of salinity and $\delta^{18} \mathrm{O}$, and the phosphate concentration of each endmember or the measured sample. We used the measured $\mathrm{NO}_{\mathrm{x}}$ (sum of nitrate and nitrite) concentration of each sample and derived individual phosphate $(\mathrm{P})$ endmembers for the Pacific and Atlantic fractions from the "pure Atlantic water line" $\left(\left[\mathrm{NO}_{\mathrm{x}}\right]=16.785^{*}\left[\mathrm{PO}_{4}\right]-1.9126\right.$; Bauch et al., 2011) and the "pure Pacific water line $\left(\left[\mathrm{NO}_{\mathrm{x}}\right]=15.314 *\left[\mathrm{PO}_{4}\right]-14.395\right.$; Jones et al., 2008) for each sample. Fixed phosphate endmember values are assigned to river water and sea-ice meltwater (Table 2).

Due to inaccuracies in endmembers and measurements, N/P-based calculations may also produce slightly negative fractions $f_{p}$ of Pacific-derived waters. These however, remain relatively small also within the Atlantic regime (average $\mathrm{f}_{\mathrm{p}}$ are $\sim-2 \%$, with extreme values up to $-10 \%)$ and are still within the uncertainty ( $10 \%$ for marine waters) of the method (Yamamoto-Kawai et al., 2008). It is a known issue that Siberian shelf waters have a similar N/P signal as Pacific-derived waters and N/P-based calculations therefore overestimate Pacific-derived waters within the TPD (Bauch et al., 2011). Alternatively, the initial phosphate corrected for mineralization with oxygen $\left(\mathrm{PO}^{*}\right)$ as quasi-conservative parameter may be used (Ekwurzel et al., 2001; Bauch et al., 2011: Newton et al., 2013). However, this method systematically underestimates the contribution of Pacific-derived water to the Arctic Ocean halocline, mainly because of continuing oxygen exchange with the atmosphere (although restricted below ice cover). Since no oxygen titration was done at station (St) 134, we applied the N/P-based method in this study. Both methods were compared and resembled each other closely considering the meteoric (slope $=1.1, \mathrm{R}^{2}=0.97, \mathrm{p}<0.0001$ ) and sea-ice melt (slope $\left.=0.91, \mathrm{R}^{2}=0.98, \mathrm{p}<0.0001\right)$ fractions in the TPD $(\mathrm{N}=80)$ as well as considering all samples ( $\mathrm{N}=432$, Figure $\mathrm{S} 1$, Table S1). Alkire et al. (2015) observed also a close resemblance between the N/P-based and PO*-based methods for $\mathrm{f}_{\text {SIM }}$ and $\mathrm{f}_{\mathrm{MW}}$. However, it must be noted that the Pacific and Atlantic contributions differ considerably, with a factor of $\sim 2$ in our data (slopes are 0.42 and 0.55, respectively, Figure S1) (Bauch et al., 2011; Alkire et al., 2015). An 
advantage of using the N/P-based method is that Charette et al. (2020) used the same method, making comparison straightforward.

A negative sea-ice meltwater fraction $\mathrm{f}_{\text {SIM }}$ reflects the amount of water removed by seaice formation, and the absolute value is proportional to the subsequent addition of brines to the remaining water. Therefore, we refer to negative fractions of sea-ice meltwater also as sea-ice derived brine influence or just brine influence. The sea-ice meltwater fraction does not include meltwater from ice formed from river water; this is river water previously transported by ice and is identified by its $\delta^{18} \mathrm{O}$ and salinity signature, and it is accounted for in $\mathrm{f}_{\mathrm{MW}}$ accordingly. All fractions are net values reconstructed from the $\delta^{18} \mathrm{O}$, salinity and the nutrient signature of each sample and are the result of time integrated effects on the sample volume over the residence time of the water.

The fractions were used to find correlations with the dissolved metals in order to investigate metal sources. Calculations were done using the software package $R(R$ Development Core Team, 2011) on all of these samples and on samples divided per basin where the TPD flowed, being the Amundsen and Makarov Basin and per crossing of the TPD, along St 81-101 and closer to the Eurasian shelf upstream the TPD along St 119-130 or 134. It was not certain whether St 134 was in or out the TPD track (see section 2.5). It must be noted that the crossing along St 119-130/134 contained more stations and samples in the Amundsen whereas the crossing along St 81-101 had more stations in the Makarov Basin (Table S4).

\subsection{Water mass distinction}

Potential temperature and absolute salinity are given in Figures 2A,B with water masses indicated. We followed Rudels (2009) to distinguish the following water masses from bottom to surface:

1. Eurasian Polar Deep Water (EPDW): potential temperature, $\Theta<-0.55^{\circ} \mathrm{C}$, approximately below $1200-1500 \mathrm{~m}$.

2. Canadian Polar Deep Water (CPDW): potential temperature between -0.55 and $-0.5^{\circ} \mathrm{C}$ and also a high salinity $>34.9$, approximately below $1900 \mathrm{~m}$. However, the upper limit of the CPDW the temperature boundary of $<-0.5^{\circ} \mathrm{C}$ did not coincide with the salinity boundary of $>34.9$. On the basis of the silicate concentrations we chose to follow the potential temperature $<-0.5^{\circ} \mathrm{C}$ to define the boundary with the above lying Intermediate Water in the Makarov Basin (IWMak).

3. Intermediate Water (IW): potential temperature between -0.5 and $0^{\circ} \mathrm{C}$, and less

This article is protected by copyright. All rights reserved. 
saline at 34.87-34.92, approximately between 800 and 1200-1550 m in the Eurasian Basins and between 800 and $1900 \mathrm{~m}$ in the Makarov Basin. As for the CPDW, the potential temperature was chosen as leading parameter to define the water mass limits.

4. Atlantic Arctic Water (AAW): potential temperature $>0^{\circ} \mathrm{C}$ and salinities between 34.5 and 35 to be found approximately between 100 and $800 \mathrm{~m}$.

5. Polar Surface Water (PSW): potential temperatures $<0^{\circ} \mathrm{C}$ with varying salinity, present in the upper 50-175 m. Along our Arctic Ocean transect the absolute salinity varied between 30.2 and $34.7 \mathrm{~g} / \mathrm{kg}$

For PDW, IW and AAW we also made a subdivision per basin, being the Nansen Amundsen and Makarov Basins. Above the relatively warm Atlantic water, the Polar Surface Water (PSW with potential temperatures below $0^{\circ} \mathrm{C}$ ) was distinguished, in which the TPD is situated. Although part of the PSW, the presence of the TPD influences the chemical composition of the PSW considerably. Therefore, the PSW is divided into in and out of the TPD track. The TPD was defined in earlier work on data of this cruise based on the in-situ Dr de Haardt fluorometer for Chromophoric Dissolved Organic Matter (CDOM) spectral ranges (BackScat, Dr. Haardt) with adsorption values above 0.5 arbitrary units (a.u.) (Slagter et al., 2017). For St 119 and 134, no CDOM data were available. For St 119, a clear distinction based on elevated DFe and $f_{M W}$, identified the position of the TPD with respect to our sample depths, however, whether St 134 was in or outside the TPD track, was unclear. In the present work, in section 4.1.2, we confirm the previous conclusion from Slagter et al., (2017) that St 134 is outside the core of the TPD. However, we disagree on St 101; we conclude that the complete upper 70 to $80 \mathrm{~m}$ of St 101 is inside the core of the TPD, whereas Slagter et al. (2017) assumed that only a small layer around approximately $70 \mathrm{~m}$ was part of the TPD, based on CDOM and DFe data.

The stations in the Barents Sea with higher temperatures $\left(\Theta: 1.4-9^{\circ} \mathrm{C}, \mathrm{S}: 34.27-35.35\right.$ $\mathrm{g} / \mathrm{kg}$ ) have been assigned to AW, except the most northern St 147, consisting of AAW.

\subsection{Statistics}

Statistics such as Pearson correlation analysis and some figures were done using R ( R Development Core Team, 2008). Other figures were made using ODV (version 5; Schlitzer et al., 2020).

A regression analysis was performed in order to judge relations between the N/P-based seawater fractions on the one hand and the different trace metals on the other hand. Seawater fractions and metal concentrations were fitted to a linear model, and contrasting pairs of

This article is protected by copyright. All rights reserved. 
least-squares means were used to examine if the regression slopes were significantly different $(\mathrm{P}<0.05)$. Analyses were performed using the lsmeans package in $\mathrm{R}$ (Lenth \& Russell, 2016; R Core team, 2020).

\section{Results}

In the Nansen Basin, the dissolved metal concentrations were relatively low at the surface and increased with depth, reaching more or less constant concentrations deeper than $700 \mathrm{~m}$ (Figures 3A-G). For the macro-nutrients the same was true, concentrations increased with depth (Figures 2C-E). However, in the upper 70 to $80 \mathrm{~m}$ of the Amundsen and Makarov Basins where the TPD was present, dissolved metals were high, decreasing with depth to more or less constant concentrations deeper than $550 \mathrm{~m}$. For the macro-nutrients, silicate and phosphate were also elevated in the TPD. When looking at the deep basins, the concentrations of most metals were lower in the Makarov Basin compared to the other basins but silicate was higher in the Makarov Basin.

In the following we present the data of average concentrations in the different water masses, considering the presence of the TPD, in the three Arctic basins and the Barents Sea, reflecting on vertical but also on lateral changes in concentrations. Lateral changes in deep water masses are made visible by giving average concentrations of IW and PDW per basin in Figure 4 and Table S2, lateral changes in upper water masses are shown in Tables S3 and S4. Figure 4 shows boxplots of the dissolved concentrations of macro-nutrients, and trace metals per water mass and additionally, for the deep water per basin. For the PSW, the TPD is shown separately. This figure clearly shows that, starting at the surface, the presence of the TPD had a large influence on the water chemistry. The TPD flow path covered part of the Amundsen and Makarov Basins between St 81-101 and 117-134 (Slagter et al., 2017; Rijkenberg et al., 2018). For DMn, DFe, DCo, DNi, DCu and silicate, average concentrations were considerably elevated in the TPD (Figures 3, 4, Table S2). The concentrations in the TPD were higher in the Makarov compared to the Amundsen Basin with the exception of nitrate, DFe and DMn (the TPD flow path did not cover the Nansen Basin, Figure 4). When concentrations are compared to PSW outside the TPD flow path, also average phosphate, DCd and DZn were higher in the TPD than in PSW outside the TPD flow path, but these higher concentrations had a patchy distribution and did not cover the full TPD extension (Figures 3A,G). During the cruise we crossed the TPD two times, once closer to the Eurasian shelf along St 119 - 130 and more downstream the TPD between St 81 and 100, crossing the North Pole. Elevated phosphate, DCd and DZn occurred downstream between St 81-101, but

This article is protected by copyright. All rights reserved. 
not upstream between St 119-130. When considering average metal concentrations in the TPD per crossing, then DMn, DFe and silicate were higher during the upstream crossing along St 119-130, whereas DZn, DCd, DNi, DCu, phosphate and silicate were higher during the downstream crossing along St 81-101, and for DCo no difference was observed. It must be noted though that DCo, DCd and phosphate had highest of all samples at St 134 (Table S3, $279 \mathrm{pM}, 0.44 \mathrm{nM}$ and $1.21 \mu \mathrm{M}$, respectively).

The overall average concentrations of silicate, phosphate, DCd and DZn were lower in PSW outside the TPD flow path compared to the underlying AAW, in contrast to the other metals (Figures 4B,C,D,J, S2A,G). However, this was caused by the relatively low PSW concentrations in the Nansen Basin. If concentrations are considered per basin, then all metals and silicate decreased from TPD to PSW outside the TPD flow path in the Amundsen and Makarov Basins and from PSW outside the TPD flow path to AAW in all three basins. Within PSW outside the TPD flow path, there was a lateral trend of increasing concentrations of the macro-nutrients and most metals from the Nansen to the Amundsen to the Makarov Basin (Table S3). Only DMn and nitrate had the highest average concentrations in the surface of the Nansen Basin, whereas average DFe was very low $(0.19 \mathrm{nM})$ in the Nansen Basin and relatively high $(0.71 \mathrm{nM})$ in the Amundsen and Makarov Basins $(0.58 \mathrm{nM})$.

In AAW, the average macro-nutrient concentrations were higher than in PSW outside the TPD flow path. There was hardly a lateral trend in this water mass, only DFe, DMn and DCo decreased slightly from the Nansen towards the Makarov Basin, whereas silicate concentrations increased $(5.29-6.1 \mu \mathrm{M})$.

Within the IW and PDW, a decrease in concentration from the Nansen towards the Makarov Basin can be seen for most metals, with the largest transition occurring between the Amundsen and Makarov Basins (Figures 3A-G, 4D-J, S2A-G). Considering the three basins, only DFe had higher concentrations in the IW of the Amundsen Basin and DZn was higher in the IW of the Nansen Basin. The concentrations of the macro-nutrients did not show a lateral trend. However, phosphate and silicate were higher in the PDW of the Makarov Basin. With depth from IW to PDW, DCd and the macro-nutrients increased in concentration, DMn and DCo decreased in concentration whereas the other metals remained constant. In the Amundsen Basin, DFe and DMn showed a maximum at St 70 at 2500-3000 m. The apparent maximum in DCd, DCu and DZn at $2565 \mathrm{~m}$ in the Nansen Basin (Figures 2A,C,G and S3A,C,G), was caused by the sample at St 32 closest to the sediment.

In the Barents Sea, lowest salinity existed in the surface on the northern and southern end of our transect (St 147 and 173, respectively, Figure 5 B) and this coincided with lowest 
silicate, nitrate, phosphate and DCd, and with highest DCo, DCu, DMn and DNi concentrations (Figures 5A-E, 6A-G). DMn, DFe and DCo had maximum concentrations near the sediment in the most northern St 147 and were less elevated near the sediment in the centre of the Barents Sea. Lowest metal concentrations were present in the middle of the transect at mid depth, where salinity was highest. Average concentrations of the macronutrients as well as concentrations of DCd, DNi and DZn were lower in the Barents Sea than in AAW in our study period (Figure 4A-C, D, I, J). The concentrations in the centre of the Barents Sea were low in the surface and increased towards the sediment with the exception of DMn.

\section{Discussion}

\subsection{Surface}

In general, profiles of dissolved metals in surface water were distinctly different when comparing in and outside the TPD (Figures 2-4, Tables S2 and S3), therefore the TPD will be discussed separately. Water mass fractions and salinity were used to indicate how important the individual sources of meteoric $\left(f_{M W}\right)$, sea-ice melt $\left(f_{S I M}\right)$, Atlantic $\left(f_{a}\right)$ and Pacific water $\left(f_{p}\right)$ were for the elevated TPD concentrations (Figure 7), as described in Bauch et al., (2011) and Charette et al., (2020).

Since $\delta^{18} \mathrm{O}$ analyses were restricted to sampled stations and depths, salinity, available for every sample, was used as support to fill gaps, although a differentiation between river and sea-ice melt could then not be made. Station 134 was not sampled with all devices present on board, therefore no CDOM fluorescence and dissolved oxygen titrations were done. CDOM fluorescence was used earlier to define the track of the TPD (Slagter et al., 2017). The question was raised whether we had crossed the TPD at St 134. Surface DFe was relatively low compared to other stations in the TPD, indicating that St 134 was outside the TPD track (Slagter 2017, Rijkenberg et al. 2018). However, here we observed that DCd, DCo, DMn, and DNi were relatively high in the surface water of St 134 compared to other stations in the TPD. Nevertheless, for all metals correlating with salinity, correlations improved excluding St 134, indicating that St 134 was outside the core of the TPD. Nevertheless, the determination of the exact boundary of the TPD core remains arbitrary (Figure 7). CDOM and $\mathrm{f}_{\mathrm{MW}}$ compare well, but $\mathrm{f}_{\mathrm{MW}}$ shows a deeper extension at stations at the boundaries of the TPD track than the 0.5 CDOM adsorption value (Table S4A; Figure 7A). This shows that not only the lateral extension but also the vertical extension of the TPD is open for debate and depending on definition.

This article is protected by copyright. All rights reserved. 
When all samples with $\delta^{18} \mathrm{O}$ and dissolved metal analyses were considered, all dissolved metals correlated positively and highly significantly with $\mathrm{f}_{\mathrm{MW}}$ except for DCd and DZn (Table S4A) implying a river source for all metals except DCd and DZn. Only DCu, DFe and DNi correlated highly significantly and negatively with $\mathrm{f}_{\text {SIM }}$, implying a sea ice formation source (brine rejection) for those metals (Table S4B). With the exception of DZn, all dissolved metals correlated positively and highly significantly with $\mathrm{f}_{\mathrm{p}}$ and negatively and highly significantly with $f_{a}$ implying the Pacific waters are a source and the Atlantic water has low metal concentrations (Table S4C,D; keeping in mind that the Pacific fraction is overestimated, the Atlantic underestimated by the applied method). Best correlations were found for DCo, DCu and DNi. It must be noted, however, that in samples with a high Atlantic fraction (>98\%) DCo correlated positively with $\mathrm{f}_{\mathrm{a}}$, but this trend was lost when all samples are considered (Figure $S 4$ ). This positive correlation at high $f_{a}$ reflects the drop in DCo with decreasing AAW. River input and the inflow of Pacific water formed a source of most metals, whereas at the time of our cruise, ice melt and Atlantic water did not.

\subsubsection{Outside the TPD track}

Although for most metals and silicate there was a clear difference between inside and outside the TPD, this was not the case for DZn, DCd, nitrate and phosphate, for which concentration differences were small or opposite (less nitrate in, than outside the TPD, Figure 4). We can thus conclude that riverine supply of these substances cannot be detected because either these were rapidly taken up by phytoplankton, which might be the case for nitrate and phosphate, or they were precipitated, or the river supply was small or not present, which was probably the case for DZn and DCd (Jensen et al., 2019, Zhang et al. 2019). Outside the TPD, in the Nansen Basin, DCd, DFe and DZn displayed a clear nutrient type profile (Figure S3A,D,G). Jensen et al. (2019) did not observe the classic nutrient type depth profiles for DZn in the entire Western Arctic. They illustrated this using a linear regression with silicate, which had different slopes than elsewhere and concluded that extra sources for DZn existed, increasing the slope $\mathrm{Zn}$ :Si from approximately $0.059 \cdot 10^{-3}$ as a global value to $0.077 \cdot 10^{-3}$ in the western Arctic (global Zn:Si from the 2017 GEOTRACES IDP: Schlitzer et al., 2018). They concluded that the $\mathrm{Zn}$ and silicate cycling were decoupled by extra input of DZn via shelf derived enrichments (see section 4.2, for discussion of such input to deep water in the current study). Even though DZn showed a nutrient type profile in the Nansen Basin, we also obtained a $\mathrm{Zn}$ :Si slope that was high compared to the global values, from $0.1 \cdot 10^{-3}$ in the Barents Sea, $0.11 \cdot 10^{-3}$ in the PSW outside the TPD track to $0.13 \cdot 10^{-3}$ in the TPD, indicating 
that shelf sources for DZn were most probably important for $\mathrm{Zn}$ in this part of the Arctic Ocean too.

Rijkenberg et al. (2018) showed there is potential for Fe limitation in the Nansen Basin, and phytoplankton consumption could be an important sink for Fe also in the Arctic Ocean. However, the other metals, DCo, DCu, DMn, DNi, showed a surface maximum in the Nansen Basin (Figure S3B,C,E,F) even though the surface maximum in the TPD was much larger. Apparently, phytoplankton consumption in the Nansen Basin was only evident in DCd, DFe and DZn distributions and not in that of the other bioactive metals, implying sources were dominant over biological uptake for those metals.

$\mathrm{DCu}$ and DNi, as well as DCo, DFe and DMn showed negative relationships with salinity outside the Barents Sea, indicating river or possibly ice melt sources (late in season) outside the TPD track (Figure S5B-F). However, no positive and significant correlations were found between these metals and $\mathrm{f}_{\mathrm{SIM}}$, whereas positive and highly significant correlations for $\mathrm{DCo}, \mathrm{DCu}$ and $\mathrm{DNi}$ and a positive and significant correlation for DFe were found with $\mathrm{f}_{\mathrm{MW}}$ (Table S4B). This riverine source of DCo, DCu, DNi, DFe and probably DMn too, is confirmed by the higher surface maxima in the river dominated TPD (section 4.1.2), but apparently riverine supply also plays an important role in the PSW outside the TPD. The slope of the DMn - salinity relationship changed between the stations, which happened also in the DCo-salinity relationships (Figure S5B,E). This change in slopes can indicate different loadings of these metals per river, local sea-ice melt, but most probably is related to the distance from the source. DMn easily precipitates as manganese oxide in seawater and is scavenged, possibly coprecipitating Co (Bundy et al., 2020; Cowen and Bruland, 1985; Moffett and Ho, 1996; Sunda and Huntsman, 1988). However, in contrast to Fe and Co, DMn is not known to be stabilized by organic complexation in the open ocean. Therefore, the station distance from the coast or shelf slope probably relates to the amount of Mn loss in the surface PSW due to precipitation, whereas salinity behaved conservatively as previously suggested by Middag et al. (2011). The conditional binding constant between Fe and organic ligands is at least a factor 100 higher than between Co and organic ligands, which might explain the coprecipitation of Co with Mn and not of Fe (Saito and Moffett, 2001; Thuróczy et al., 2011; Dulaquais et al., 2014, 2017; Slagter et al., 2017). Unfortunately, our station positions versus the shelf slope do not allow an in-depth study of declining metal concentrations versus distance from the shelf slope.

\subsubsection{The influence of the TPD}

This article is protected by copyright. All rights reserved. 
In earlier work (Slagter et al., 2017), CDOM fluorescence was used to define the track of the TPD during our cruise. And indeed, CDOM fluorescence correlated very well with $\mathrm{f}_{\mathrm{MW}}$, either when all samples were considered or when considering samples per basin (Table S4A, $\mathrm{R}^{2}>0.76$; $\mathrm{p}<1 \mathrm{e}-15$ for N/P-based; not shown in Table $\mathrm{S} 4: \mathrm{R}^{2}>0.80$ for PO*-based). However, when only samples in the TPD were considered, CDOM fluorescence correlated less well with $\mathrm{f}_{\mathrm{MW}}$, although still highly significant (Table $\mathrm{S} 4 \mathrm{~A}, \mathrm{R}^{2}=0.38 ; \mathrm{p}<1.5 \mathrm{e}-5$ ). The reduction in significance is probably due to the deeper extension of the TPD according to $\mathrm{f}_{\mathrm{MW}}$ (Table S4A; Figure 7) and also related to the decrease in sample number. As already suggested in section 4.1, we confirm that we had already crossed the core of the TPD when sampling St 134. St

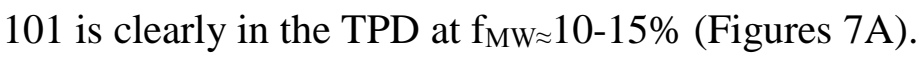

The riverine source for the metals DCo, DCu, DFe, DNi, and DMn, already clear in the PSW, is confirmed here by the highly significant correlations with $\mathrm{f}_{\mathrm{MW}}$, considering all samples (Table S4A, Figures 8, S6), as also observed by Charette et al (2020) in the upper 50 m of a combined transect of the Geotraces GN01 and GN04 (=this cruise) cruises over the North Pole, including our St 81-101. Comparing with Charette et al. (2020), most correlations have comparable slopes and intercepts, especially when comparing with the downstream crossing of the TPD. (Table S4, their Table 1, Figure S6). The transect discussed by Charette et al. (2020), contained our data from St 70-101 and continued into the Canadian Basins using data from the GN01 transect. The data in the present study from only GN04 contains samples from stations closer the shelves and shelf slopes (St 117-133) more upstream of the TPD, not discussed by Charette et al. (2020). For DMn, our study shows a steeper slope at the upstream crossing of the TPD. The distance from the source is negatively related to the DMn concentration, most likely due to precipitation (see text section 4.1.1). Therefore, we postulate the steeper slope we obtained in the upstream crossing of the TPD, St 117-133, is a consequence of being closer to the riverine sources.

A second difference with Charette et al. (2020), is that they also found a significant relationship between $\mathrm{f}_{\mathrm{MW}}$ and $\mathrm{DCd}$, whereas we did not. It must be noted that the slopes from this study and from Charette's are small $(<|0.004|$ and 0.01 , respectively) indicating that DCd does not vary much due to river input. Moreover, when considering our data per basin for DCd, highly significant correlations existed between DCd and $\mathrm{f}_{\mathrm{Mw}}$ only in the Amundsen and the Makarov Basin, however in the Amundsen a negative slope was found and, in the Makarov a positive slope. And since DCd had a significant negative correlation with $\mathrm{f}_{\mathrm{a}}$, and a significant positive correlation with $\mathrm{f}_{\mathrm{p}}$, the Pacific influence is probably interfering here with the sign of the slope of the correlations with $\mathrm{f}_{\mathrm{Mw}}$.

This article is protected by copyright. All rights reserved. 
The fact that the regression slopes between DCd and the fractions are so low, probably reflects interference of the dominant, Pacific influence.

The best positive linear relationships existed between $\mathrm{f}_{\mathrm{MW}}$ and $\mathrm{DCu}$ and $\mathrm{DNi}\left(\mathrm{R}^{2}\right.$ between 0.45 and 0.67 , Table S4A, Figure 8C, F; even more significant correlations $\mathrm{R}^{2}>0.9$, existed for $\mathrm{PO}^{*}$-based $\mathrm{f}_{\mathrm{MW}}$ and $\mathrm{DCu}$ and $\mathrm{DNi}$ ). For $\mathrm{DCu}$ and $\mathrm{DNi}$, the maxima in dissolved metal concentrations coincided perfectly with maximum $\mathrm{f}_{\mathrm{MW}}$ (Figures $8 \mathrm{C}$, F), which together with the regressions form a strong indication of the importance of rivers as source of these metals to the Arctic Ocean. Both metals had comparable slopes with $\mathrm{f}_{\mathrm{Mw}}$ for every set of samples tested (Table S4A). These comparable slope values are a strong indication that Arctic rivers are a consistent source of these metals, as was also noticed for the Canadian Basins (Charette et al., 2020), with little variation between different rivers whereas for other metals there seems differentiation as discussed below.

In our study the focus is more on the Amundsen Basin than in the study of Charette (2020), and we compare the relationships with the source fractions and the metals for our complete transect, including the two crossings of the TPD. The two crossings showed small differences in the slopes of the correlations, which might be due to contributions of different Eurasian rivers. Paffrath et al. (2021) indeed showed, using Nd isotopes and concentrations, that the contribution of the different Siberian rivers varies between the stations and with depth, potentially also explaining the variation in metals. The $\mathrm{Nd}$ isotope-based river signals can still be distinguished in the TPD and down to $\sim 100 \mathrm{~m}$ water depth with a vertical and lateral separation of Lena water in the Laptev Sea shelf water overriding Yenisei/Ob water in Kara Sea shelf water. Due to their different salinities, the different shelf waters do not mix along the transport towards the Fram Strait. Rare earth elements (Paffrath et al., 2021) had lower concentrations at St 101 (Makarov Basin) compared to the other sampled station (St 125 (Amundsen Basin) and St 96 (Makarov Basin)), and Nd isotopes, in combination with sea-ice melt corrected salinities, indicated the presence of Lena River and likely Yenisei/Ob River contributions. However, even though for the metals more stations were sampled such clear differentiation could not be observed in the trace metals distributions, but nevertheless the different riverine endmembers likely contributed to the observed variation in trace metal concentrations in the TPD.

The crossing along St 119-130 upstream in the TPD showed higher slope values between $\mathrm{f}_{\mathrm{MW}}$ and DFe and DMn and lower slope values for DCu and DNi compared to the downstream crossing along St 81-101. However, with the exception of DMn, the differences between slopes were only significant when the slopes of all samples $(\mathrm{N}=217$ where both 
fractions and metals were available) were compared to those in the TPD (N=31, Tables S4 and S5). The regression slopes between the two crossings only differed significantly for DMn (Table S5), but as discussed above (section 4.1.1) this indicates the relative loss in the direction of the TPD flow path probably due to precipitation of DMn as oxides (Middag et al., 2011; Jensen et al, 2020.).

Although $\mathrm{f}_{\mathrm{MW}}$ related very well with DCo, DFe and DMn (Table S4A, Figures 8B,D,E, $\mathrm{S} 6 \mathrm{~B}, \mathrm{D}, \mathrm{E})$ a river source cannot explain features at the border of the TPD. For example, on the Makarov side of the TPD at St 101, just within the TPD core, and at St 134 just outside the TPD core, trends in $\mathrm{f}_{\mathrm{MW}}$ did not coincide with trends in these metals. For DFe, relatively low concentrations with high $\mathrm{f}_{\mathrm{MW}}$ coexisted, whereas for DCo and DMn the reverse was true, relatively high, even maximum concentrations coexisted with low $\mathrm{f}_{\mathrm{MW}}$, where this low $\mathrm{f}_{\mathrm{MW}}$ is indicative of the border of the TPD track $\left(\mathrm{f}_{\mathrm{MW}} \approx 14.5 \%\right.$ at St 101 and $\mathrm{f}_{\mathrm{MW}}<5 \%$ at St 134, versus $\mathrm{f}_{\mathrm{MW}}>10 \%$ in the TPD core). At these stations high $\mathrm{f}_{\mathrm{p}}$ and $\mathrm{f}_{\mathrm{SIM}}$ occurred and DFe, and probably CDOM, were diluted by the contributions of Pacific and sea-ice melt water, whereas DCd, DCo, DCu, DMn and DNi were enriched. During the long transport over the Bering Strait and Chukchi shelf and Canadian basins, melting, refreezing and brine rejection likely distorted the correlation between metals and $\mathrm{f}_{\mathrm{MW}}$ for stations with high $\mathrm{f}_{\mathrm{SIM}}$. This makes interpretation of the data from St 101 and 134 difficult. Further enrichment of these metals by Pacific water is likely related to the long passage over the Bering shelf and associated interaction with the sediments (Zhang et al., 2019; Bundy et al., 2020, Jensen et al., 2020). The question arises why Pacific surface water was enriched in these metals (DCd, DCo, DCu, DMn and DNi) during passage through shallow coastal seas and DFe was not. A possible explanation was given by Jensen et al. (2020), they described the phases in the chemistry of Fe and Mn during transport over the shelf into the basins. Fe and Mn, as well as Co, were released from the sediment, where it is known that the oxidation kinetics of DFe are much faster than of DMn (Stumm, 1981; Millero et al., 1987) resulting in an initially much faster decrease of Fe in the dissolved phase. However, when DFe has decreased to the level that can be kept in solution by Fe binding organic ligands, the remaining Fe is stabilised (Thuróczy et al., 2011; Slagter et al., 2017; 2019). The average lifetime of these ligands was established to be at least twice that of Fe in the Western Atlantic Ocean (Gerringa et al., 2015). Assuming this is also the case in the Arctic Ocean, the complexed DFe will decrease with distance from the source by dilution only, whereas DMn will also continue to decrease due to oxidation and precipitation. The position of St 134 with a high Pacific fraction, apparently still had a relatively high DMn and DCo concentration, supposedly because time for transport from the shelf edge was too short

This article is protected by copyright. All rights reserved. 
for complete Mn oxidation and co-precipitation of Co. In contrast, DFe was relatively low, at a concentration set by dissolved organic ligands, because transport to St 134 was outside the organic rich TPD and the organic ligand concentration was low (Slagter et al., 2017; https://doi.org/10.1594/PANGAEA.890975). The role of stabilising Co binding organic ligands here is less clear. Bundy et al (2020) found the highest \% of labile Co (not bound to organic ligands) over the shelf. This fraction decreased more rapidly with distance from the shelf than DCo. Thus, ligands likely do play a role in stabilising Co.

Variations in surface DCd and DZn cannot be explained by meteoric contributions as no correlations were found with $\mathrm{f}_{\mathrm{MW}}$, even though these metals had on average higher concentrations in the TPD than in the PSW outside the TPD flow path, implying a riverine source (Figures 4D,J, S2A,G). DCd correlated highly significantly with $\mathrm{f}_{\mathrm{p}}$ when considering all samples, as well as samples in the PSW outside and inside the TPD flow path, and in the Makarov Basin and with $\mathrm{f}_{\mathrm{SIM}}$ considering samples only in the Amundsen Basin (Table S4B,C). The few Arctic data of Cd that exist, showed that elevated Cd in Pacific water coming from the Bering Strait (Zhang et al., 2019; Jackson 2017; Cid et al., 2012; Moore, 1981; Yeats, 1988) caused high subsurface DCd (70-150 m) in the Canadian Basin. The two profiles sampled by Yeats (1988) clearly show the difference in sub-surface DCd on both sides of the Lomonosov Ridge, subsurface DCd up to $0.8 \mathrm{nM}$ in the Canadian Basin versus $0.2 \mathrm{nM}$ in the Eurasian profile. This also explains the current observed relationship with the $\mathrm{f}_{\mathrm{p}}$ where sources of DCd were Pacific surface waters and apparently additional sea-ice melt. For DZn we did not see any consistent correlation with the 4 fractions, apparently the sources distinguished here do not carry a specific, characteristic DZn.

\subsection{Barents Sea}

In the Barents Sea, with high salinity (34.27- 35.35), DCo, DFe and DMn concentrations were high, higher than in the Arctic Ocean, with the exception of the TPD as was also observed over the Chukchi shelf/Bering Strait (Bundy et al., 2020; Jensen et al., 2020) (Figure 6). A strong relationship existed between salinity and most parameters where lower salinity coincided with higher DCo, DCu, DMn and DNi. Both locations with the lowest salinity in the upper 50-70 m (St 147 and 173) were relatively close to land (Figures $1 \mathrm{~B}, 6)$, Svalbard and the mainland of Norway, respectively. No samples for $\delta^{18} \mathrm{O}$ were taken, thus a definite distinction in water mass fractions is not possible. According to Klunder et al.

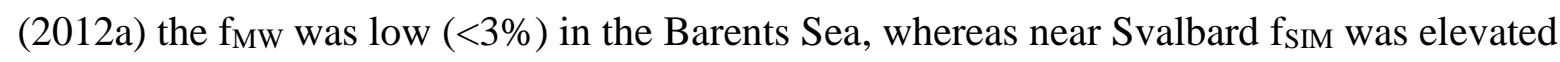
up to $5 \%\left(\mathrm{St} 147,75^{\circ} \mathrm{N}\right)$. Elevated concentrations of DCo, DMn and also DCu and DNi in the 
surface of the southern (St 173) and northern (St 147) stations were probably due to sea ice melt and for St 147 possibly also to runoff from Svalbard. Primary productivity in this region consumed silicate, nitrate, phosphate and this must also have reduced the surface concentrations of the bio-active metals, however, this was only visible in the vertical profiles of DCd, DFe, DNi and DZn. Input from the sediments was visible in high bottom concentrations for all metals, especially for DCo, DFe, DMn and DZn near St 147, and was least important for DCd, DNi and DCu. Assuming the high salinity in the centre of the transect (Figure 5B, 6A-G) as the core of the AW, it is clear that AW had relatively low dissolved metals concentrations and thus enrichment in the AAW, as seen in the Nansen Basin for DCo, DFe and DMn, was derived predominantly from the sediment and for DCo and DMn also derived from sea ice melt. Because of the extensive primary production and scavenging in the Barents Sea, affecting the trace metal outflow we are hesitant to consider the Barents Sea section as endmember representative for the total inflow of Atlantic water to the Arctic Ocean.

Sampling during the first weeks of October illustrated that in this period, the Barents Sea serves as source for DFe into AAW, as seen also by Klunder et al., (2012a) and Rijkenberg et al. (2018), for DMn as also concluded by Middag et al. (2011) and for DCo as also concluded by Bundy et al. (2020) for the Chukchi Sea. Probably the Barents Sea serves as a source for DZn as observed by Jensen et al. (2019) for the Chukchi Sea, and for DCu, considering the high maximum concentrations in the Barents Sea (Table S2). No indications were found for outflow of DCd from the Barents Sea into the Arctic Ocean. This agrees with the explanation that the small concentration difference between EPDW and CPDW could be related to little Cd coming from the Eurasian shelves, in contrast to the input of DCd release from the Bering Strait and Chukchi Shelf (Zhang et al., 2019).

\subsection{Deep waters}

The concentrations of dissolved metals in deep waters increase due to lateral sources, inflow of AAW and input from the shelves and continental slopes, as well as point sources from hydrothermal input, whereas scavenging leads to reductions in concentrations as discussed in separate subsections below.

\subsubsection{Importance of lateral input}

Indications of lateral input are expected to be seen as decreasing concentrations from the sources, being the shelves in AAW, IW and PDW. The concentrations of most dissolved 
metals varied considerably in the Barents Sea, however, considering average concentrations it is clear that DCo, DFe and DMn were higher in the Barents Sea than the AAW (Figures 4E,G, $\mathrm{S} 2 \mathrm{~B}, \mathrm{D}, \mathrm{E})$. Moreover, DMn in the AAW was higher than in the IW in the Nansen Basin whereas DCo was elevated in AAW and IW compared to the deeper water indicating also vertical exchange of DCo. No such differences existed for average DCd, DCu, DNi and DZn. Maximum DCd, near the sediment in the Barents Sea (0.22 nM, Table S2) was hardly higher than the average concentrations in the AAW $(0.2 \mathrm{nM})$. However, maximum DZn in the Barents Sea reached concentrations up to $1.83 \mathrm{nM}$, and maximum DCu reached $2.52 \mathrm{nM}$, values not found in the AAW. At St 32 (314 km NE of the continental slope) maxima of DCo, DFe, DMn and DZn occurred in the AAW. Specifically, DCo remained elevated in the AAW and IW further in the Nansen and Amundsen Basins and decreased less with distance compared to DMn (Figure 3B,E). We sampled perpendicular to the continental slope, which was also more or less perpendicular to the general circular counter clockwise current of the AAW (Rudels et al, 2011; Rudels, 2012). We compared the steady lateral decline of DCo in the AAW with distance from the continental slope with that of salinity. However, it must be noted that our sampling strategy gives an underestimation of the transport of metals in the AAW, since we sampled across and not along the AAW pathway. The scale length was calculated assuming diffusion from a point source, i.e. the shelf, to the average value observed in the Makarov Basin (52.7 pM DCo and S=34.99, in the AAW, approximately between 200 and $800 \mathrm{~m}$, where the potential temperature was $>0^{\circ} \mathrm{C}$ ) (Johnson et al. 1997; Bucciarelli et al. 2001). The scale length is the distance where the decrease in concentration from the point source on the shelf was $1 / 3$ of the total decrease from the shelf to the center of the Makarov Basin. Even though the influence of sea-ice melt, and other factors influencing these parameters were neglected, the scale lengths for DCo and absolute salinity were quite similar at $615 \mathrm{~km}$ and $790 \mathrm{~km}$, respectively. Assuming that almost $92 \%$ of DCo was organically complexed as reported by (Bundy et al., 2020) for the Western Arctic Ocean, apparently the organic ligands stabilize Co also in the Eastern Arctic Ocean, leading to near conservative behaviour.

Middag et al. (2011) concluded that for DMn, apart from river and hydrothermal input, lateral input from shelves was an important source for DMn in 2007 by transport along the continental slope. However, we had only one station near the shelf edge in the Nansen, St 32. Here indeed elevated DMn (1.13 nM) existed until at least 500 depth $\mathrm{m}$ in the AAW, but no evidence of lateral input could be seen at larger depths in the current data set. This is similar 
to the previous observations where minima in transmission and maxima in DMn faded away with increasing distance from the shelf, supposedly due to along slope currents that prevent direct transport towards the central basin (Middag et al., 2011).

Schlosser et al. $(1990,1997)$ estimated the age or residence times of the different water masses and concluded based on the variation in ages of the water masses, that the circulation is decoupled. They estimated that the residence time of PSW is approximately 7 years where the TPD crosses the Arctic in 1-3 years (Pfirman et al., 1997; Charette et al., 2020). The residence times of AAW and IW are approximately 7-9 and 15 to 20 years, respectively, whereas the PDW resides 200-250 years in the deep basins on the Eurasian side of the Arctic and 450 years in the deep Makarov Basin (Schlosser et al., 1994). Thus, the deep water masses hardly mix, which can be recognised in the distribution of DCo, with different concentrations per water mass (Figure 3B, S2B), but not for the other metals. DZn decreased with distance from the shelf in the Nansen Basin in a thick layer comprising AAW, IW and PDW in the Nansen Basin, between 3500-500 m at St 32-50 to 2000-500 m at St 58 (Figure 3G). Additionally, at St 117-125 (the far end of the transect) in the Amundsen Basin, elevated DZn extended between 1200-2500 m, specifically in PDW in the Amundsen Basin. The shelf slope is the most probable source of elevated DZn in both the Nansen and Amundsen Basins in AAW, IW and PDW and this might be transported into the IW as far as the Makarov Basin. As already discussed in section 4.1.1, Jensen et al. (2019) concluded that the change in slopes of the DZn-silicate relationship per depth layer indicated DZn was not only governed by remineralization but that lateral input formed a main source of DZn. We found a large variation in DZn-silicate slopes in the AAW, IW and PDW, from $0.17 \mathrm{nM} / \mu \mathrm{M}$ in the Nansen IW to $-0.17 \mathrm{nM} / \mu \mathrm{M}$ in the Nansen PDW (Table S6). The DZn data in this study (Figure 3J) thus confirm the conclusion of Jensen et al. (2019) that the change in $\mathrm{Zn}$-Si relationships is likely due to lateral input of DZn from the shelf slope as was previously suggested for Al (Middag et al., 2019).

\subsubsection{PDW in the Amundsen and Makarov basins}

The feature that stands out most in the distribution of trace metals in the deep basins, with the possible exception of DCd, is the highly significant difference between the relatively low concentrations in the Makarov Basin and the relative high concentrations in the Eurasian Basins, specifically the Amundsen Basin (Figure 9). We discuss three explanations for these differences, hydrothermal activity, scavenging and slope convection.

This article is protected by copyright. All rights reserved. 
Hydrothermal inputs on the Gakkel Ridge (Edmonds et al., 2003) are clearly visible in the distribution of Fe and Mn (Klunder 2012, Middag, 2011), and also silicate. No hydrothermal activity is known in the Canada Basin, and none is expected based on seismic evidence. This can form an explanation of the relatively high DFe and DMn, but not for most other metals discussed here.

The accumulation in the Makarov Basin of the natural radionuclides ${ }^{230} \mathrm{Th}$ and ${ }^{231} \mathrm{~Pa}$, which are continuously produced in the water column, to values in excess of the values in the Eurasian Basin (Bacon et al., 1989; Scholten et al., 1995, Grenier et al., 2020) imply that scavenging rates in the Eurasian Basin are higher than in the Makarov Basin. The hydrothermal inputs contribute through oxide formation to this enhanced scavenging (Valk et al., 2018). Additionally, scavenging is also controlled by the flux of particles from other origins. Particle flux rates in the ice-covered ocean are low as illustrated by a beam attenuation section across the Arctic Ocean. However, enhanced turbidity, implying enhanced scavenging, is observed in the boundary current along the Nansen slope and in the return current along the Lomonosov Ridge in the Amundsen Basin. Edmonds et al. (2004) concluded that scavenging rates in the central Canada and southern Makarov Basin were intermediate between these high values near the slope and the extremely low scavenging rates that had been observed on the Alpha Ridge and in the central Makarov Basin (Bacon et al., 1989; Scholten et al., 1995). The apparent low scavenging rates in the Makarov Basin that were inferred from the contrast in radionuclide concentrations, only seem to contradict the contrast in trace metal concentrations between the Eurasian and Canadian basins. One would assume that lower scavenging rates would lead to higher concentrations of most trace metals, however, time and hydrography should also be considered.

The intermediate and deep waters in the Canadian Basin, including the Makarov Basin, are warmer, saltier, and richer in dissolved silicate than the deep waters in the Eurasian Basin. The ultimate source of these deep waters must be brine formation and shelf-slope convection. The difference between the basins is explained by the longer exposure to shelf-slope convection in the Canadian Basins compared to the Eurasian Basins (Rudels, 2015). Nutrient regeneration on the shelf is the source of the high nutrient and especially high silicate concentration in the upper halocline (Anderson et al., 2017; Jones and Anderson, 1986) and this enrichment must also be the source of the silicate enrichment in the deep Canadian Basins.

Apart from sources, it is important to consider the time scales of the renewal of the deep water masses in the basins. Schlosser et al. (1994) estimated a deep water ${ }^{14} \mathrm{C}$ age of $200-250 \mathrm{y}$ 
for the Eurasian Basin Bottom water and $450 \mathrm{y}$ for the bottom water of the Canadian Basin (Makarov and Canada Basins). Macdonald et al. (1993) hypothesized that the renewal of the Canada Basin deep water might in fact not be continuous but the deep water might be a relic of an overturning event 500 years ago. This hypothesis obtained further support by considerations of Timmermans et al. (2003) on the strength of the stratification in the basin and by the extremely slow penetration of transient tracers in the deep water of the Canadian Basin (Smethie et al., 2019). The present low salinity of surface water in the Canadian Basin likely prevents the formation of sufficiently dense deep water. Although a heat budget (Timmermans and Garrett, 2006) and the Al distribution (Middag et al., 2009) suggest a slight inflow of Amundsen Basin water over the Lomonosov Ridge into the deep Makarov Basin, the deep waters in both the Makarov Deep water might be regarded as nearly stagnant water masses after a ventilation event some 500 years ago. The ${ }^{14} \mathrm{C}$ age of the Eurasian Basin Bottom water is younger, and it is known that this deep water exchanges with the deep water in the Greenland Sea. Additionally, deep water renewal is continuing where deep waters are a mixture of relic deep waters and new admixtures from shelf convection (Aagaard, 1985; Rudels, 2015, Smethie, 2019). This was further supported by the accumulation of $\mathrm{Al}$ in the deep water of the Eurasian basin that was explained by inputs from shelf-slope convection by Middag et al. (2009) as these authors found higher Al concentrations in the deep Eurasian Basin compared to the deep Makarov Basin.

We hypothesize that the highly significant concentration contrast in deep water of all dissolved metals in this research with the exception of DCd is caused by the much lower present-day input of terrigenous and shelf material into the deep Makarov Basin by shelfslope convection. Scavenging at very low rates, but maintained over several centuries, may further reduce the trace metal concentrations in the Makarov Basin. This last hypothesis is supported by the increase in excess Fe-binding ligand sites with depth in the Makarov Basin (Thuróczy et al., 2011; Slagter et al., 2017). This increase of empty sites with depth is usually not observed in deep water, with the exception of the Mediterranean Sea (Gerringa et al., 2017). In deep ocean water, ligand sites generally get more saturated with Fe with increasing depth, as also found in the Amundsen and Nansen Basins. This deviation of increasing empty sites with depth can be explained by long exposure to scavenging, that leads to ligand sites being outcompeted and decreasing DFe concentrations in the Makarov Basin.

The contrast in DCd between the PDW in the Makarov and Amundsen Basins is less significant than for the other metals ( $p=0.01$ versus $<0.001$ in Figure 9D). This may be because hardly any $\mathrm{Cd}$ is coming from the shelves into the Eurasian basins and/or $\mathrm{Cd}$ is not

This article is protected by copyright. All rights reserved. 
very susceptible to scavenging, a feature that also contributes to strong nutrient type distribution (Hendry et al., 2008; Bruland et al., 2014; Quay et al., 2015; Middag et al. 2018).

\section{Conclusions}

In the Barents Sea, the input from the sediments was the most probable source of metals and at the time of sampling, the first weeks of October, the Barents Sea served as source into the AAW for DFe and for DCo, possibly for DZn and DCu, but not for DCd and DNi. At the two ends of the transect through the Barents Sea, lowest salinity occurred relatively close to land together with higher $\mathrm{DCo}, \mathrm{DCu}, \mathrm{DMn}$ and $\mathrm{DNi}$, an indication of terrestrial input from Svalbard on the north side and the mainland of Norway at the southern side.

In the surface PSW, inside and outside the TPD, clear indications were found for riverine sources for $\mathrm{DCu}, \mathrm{DNi}, \mathrm{DCo}, \mathrm{DFe}$ and $\mathrm{DMn}$ by highly significant $(\mathrm{p}<<0.001)$ correlations with $\mathrm{f}_{\mathrm{MW}}$. The correlations between $\mathrm{f}_{\mathrm{MW}}$ and the dissolved metals compared well with results from Charette et al. (2020), with the exception of DMn and DCd. We found a steeper slope for the fMW-DMn correlation compared to Charette et al. (2020), and significant changes in slope of this correlation between stations, indicating the precipitation of Mn along the transport of the TPD. DCd was positively correlated with Pacific water and no indications were found for a river source.

In the Makarov Basin just outside the TPD core, DCo, DMn, DNi, DCd and DCu were enriched by Pacific water whereas this inflow diluted DFe. The enrichment is likely related to the long passage over the Bering shelf (Bundy et al., 2020, Jensen et al., 2020), whereas the dilution of DFe is supposedly caused by the contrast in organic ligands between Pacific water and organic rich TPD.

Consumption by phytoplankton in surface waters resulted in nutrient type profiles for DCd, DFe and DZn in the Nansen Basin, and thus we postulate that surface depletions of these metals are likely to expand upon future reduction in sea-ice coverage. Lateral input from the continental slopes into the Eurasian Basin was the main source for DZn at depths. Indications for lateral DCo and DMn inputs were present but not as evident as for DZn.

Highly significant differences in deep water metal and macro-nutrient concentrations existed between the Eurasian and Makarov Basins. All metals have higher concentrations in the Eurasian basins whereas silicate and phosphate have lower concentrations. At the Gakkel Ridge a very local hydrothermal input of DFe and DMn and silicate was observed, forming 
one of the explanations for higher concentrations of these metals in the Eurasian basins. Another explanation is higher input into the deep Eurasian Basins via shelf slope convection. The long residence time of the deep water in the Makarov Basin, even though the scavenging rate is low, most likely also contributes to the lower metal content in this deep basin. A similar explanation was previously suggested to explain the increase with depth in excess $\mathrm{Fe}$ binding ligand sites in the Makarov Basin (Thuróczy et al., 2011; Slagter et al., 2017). These authors assumed that over the very long residence time of deep water, the ligand sites were outcompeted by scavenging.

Overall, our results demonstrate the distribution of bio-active metals in the Arctic Ocean is governed by fluvial input as well as shelf sources and internal cycling on the other hand. Notably scavenging plays an important role, especially in the deep basins, but biological uptake must play a role in the surface ocean as well. This uptake is likely to become more important since ongoing warming in the Arctic leads to decreasing ice cover, which increases light penetration and primary production and hence increases uptake of bio-active metals. On the other hand, increasing temperatures also lead to increased discharge of Arctic river water from snow and ice melt as well as permafrost thawing, which would increase supply of metals to this region. Enhanced productivity and fluvial supply not only affect the surface ocean, it will also affect scavenging intensities over the entire water column as both productivity as well as river run off are expected to increase the concentrations of particulate matter (Grenier et al., 2019). We postulated differences in scavenging intensities and water residence times are responsible for differences between deep basins, so changes in scavenging intensities will likely affect the metal distributions. Additionally, recent results based on ${ }^{129}$ I suggest circulation in the Arctic Ocean is changing (Smith et al., 2021), which also would affect metal and particle distributions, and thus scavenging intensities. It is clear that the Arctic Ocean is in a transient stage and eventually a new equilibrium will establish, but further monitoring is needed to predict what will happen to trace metal biogeochemical cycling in the Arctic Ocean where this study provides a baseline to assess future changes.

\section{Acknowledgements}

We would like to thank PI Ursula Schauer, captain Schwarze and the crew of FS Polarstern on expedition PS94, as well as the Alfred Wegener Institute for logistical support. We thank Jan van Ooijen for his nutrient analyses on board. Aridane Gonzalez, Lars-Eric Heimburger and Michael Staubwasser are recognized for their assistance in

This article is protected by copyright. All rights reserved. 
trace metal clean sampling, Sven Ober for the operation and maintenance of the PRISTINE sampling system. Our participation in this GEOTRACES expedition was funded by NWO under contract number 822.01.018 to L.J.A. Gerringa. D. Bauch was funded for this project by DFG (BA1689/2-2).

Nelleke Krijgsman is thanked for making and improving the composite figures.

We are grateful for the positive comments of two anonymous reviewers, improving our manuscript considerably.

Data Availability

The data is available at https://dataportal.nioz.nl/doi/10.25850/nioz/7b.b.jc.

This article is protected by copyright. All rights reserved. 
Figure captions

Figure 1. The Arctic Ocean with geographic features and stations sampled in the Barents Sea and along the Arctic Ocean transect.

A: The shelf seas and three main Eurasian rivers. The flow path of the TPD (yellow) is indicated and the currents of the Atlantic Water (AW) transforming into Atlantic Arctic Water along its way through the Arctic Ocean and Barents Sea. Blue dots indicate stations sampled for dissolved trace metals with the trace metal clean CTD.

B: Map with the Arctic Ocean transect (red box) and the Barents Sea transect (green box) and stations (with station numbers) sampled for nutrient analysis indicated by blue dots. These were analysed in samples obtained with the standard and the trace metal clean rosettes.

The basins and ridges mentioned in the text are indicated.

Figure 2. Depth distribution in the Arctic transect (Figure 1B) of A: potential temperature $\left({ }^{\circ} \mathrm{C}\right)$; B: absolute salinity $(\mathrm{g} / \mathrm{kg}), \mathrm{C}$ : nitrate $\left(\mathrm{NO}_{3}{ }^{-}\right), \mathrm{D}$ : phosphate $\left(\mathrm{PO}_{4}{ }^{3-}\right), \mathrm{E}$ : silicate $\left(\mathrm{Si}(\mathrm{OH})_{4}\right)$. Figures $\mathrm{C}-\mathrm{E}$ are in $\mu \mathrm{M}$. The temperature transect shows the water masses based on definitions from Rudels, (2009), indicated by potential temperature isolines at $-0.55,-0.5$ and $0{ }^{\circ} \mathrm{C}$ as boundaries between IW and EPDW, IW and CPDW and AAW and PSW and IW. These temperature isolines are also drawn in figures C-E.

Figure 3: Depth distribution in the Arctic transect (figure 1B) of dissolved metals in nM, except DCo in pM. A: DCd, B: DCo, C: DCu, D: DFe, E: DMN, F: DNi, G: DZn. Station numbers are indicated in G. Temperature isolines at $-0.55,-0.5$ and $0{ }^{\circ} \mathrm{C}$ as boundaries between IW and EPDW, IW and CPDW and AAW and PSW and IW are drawn in all figures.

Station numbers are indicated in $\mathrm{G}$.

Figure 4: Boxplots of the dissolved concentrations of macro-nutrients, and trace metals of all stations per water mass as defined by Rudels (2009). 4A-C the nutrients are in $\mu \mathrm{M}$, 4D-J: dissolved metals are in $\mathrm{nM}$, with the exception of DCo which is in pM. The median values are indicated by the thick horizontal line in the boxes, which contain the first and third quartiles, whereas the whiskers indicate the range excluding outliers. Circles are outliers (>1.5 interquartile range from the box, Teetor, 2011). The figures are 
made using the software package R. In figure S2 the same data is shown but using different vertical scale to better show differences between deep water masses.

A: nitrate, B: phosphate, C: silicate, D: DCd, E: DCo, F: DCu, G: DFe, H: DMN, I: DNi, J: DZn.

Figure 5: Depth distribution in a transect in the Barents Sea with latitude on the $\mathrm{x}$ axis (green annotated transect in Figure 1B) of A: potential temperature $\left({ }^{\circ} \mathrm{C}\right), \mathrm{B}$ : absolute salinity $(\mathrm{g} / \mathrm{kg})$ isolines have an equidistance of $0.05, \mathrm{C}$ : nitrate $\left(\mathrm{NO}_{3}{ }^{-}\right), \mathrm{D}$ : phosphate $\left(\mathrm{PO}_{4}{ }^{3-}\right)$, E: silicate $\left(\mathrm{Si}(\mathrm{OH})_{4}\right)$. Figures $\mathrm{C}-\mathrm{E}$ are in $\mu \mathrm{M}$. Isolines of absolute salinity are added to figures C, D, E, the equidistance being $0.1 \mathrm{~g} / \mathrm{kg}$. Station numbers are indicated in E. The distance between St 147 and 173 is $456.5 \mathrm{~km}$.

Figure 6: Depth distribution in a transect in the Barents Sea with latitude on the xaxis (green annotated transect in Figure 1B) of dissolved metals in nM except for DCo in pM. A: DCd, B: DCo, C: DCu, D: DFe, E: DMN, F: DNi, G: DZn. Station numbers are indicated in figure $5 \mathrm{G}$. Isolines of absolute salinity are added to the figures, the equidistance being $0.1 \mathrm{~g} / \mathrm{kg}$.

The distance between St 147 and 173 is $456.5 \mathrm{~km}$.

Figure 7: The upper $150 \mathrm{~m}$ of the Arctic transect with fractions of A: meteoric $\left(f_{M W}\right), B$ : Pacific $\left(f_{p}\right), C$ : sea-ice melt $\left(f_{S I M}\right)$ and $D$ : Atlantic water $\left(f_{a}\right)$, as determined by $\delta^{18} \mathrm{O}$ based on N/P. Station 101 is positioned at $1852 \mathrm{~km}$.

Figure 8: Depth distribution along the Arctic transect of dissolved metals (nM except DCo in $\mathrm{pM}$ ) in colour scale and the meteoric $\delta^{18} \mathrm{O}$ fraction ( $\left.\mathrm{f}_{\mathrm{MW}}\right)$ as an overlay in contours. A: DCu, B: DNi, C: DCD, D: DZn, E: DCo, F: DFe, G: DMn. Figures are made with ODV (Schlitzer, R., 2020).

Figure 9: Boxplots from the Welch two sample t-test, comparing PDW from the Amundsen and Makarov Basins, as defined by Rudels (2009) for the dissolved concentrations of macro-nutrients, and trace metals. Figures 9A-C are in $\mu \mathrm{M}$, dissolved metals are in $\mathrm{nM}$, with the exception of DCo which is in pM. A: nitrate, B: phosphate, $\mathrm{C}$ : silicate, D: DCd, E: DCo, F: DCu, G: DFe, H: DMN, I: DNi, J: DZn. The median values are indicated by the thick horizontal line in the boxes, which contain the first and third 
quartiles, whereas the whiskers indicate the range excluding outliers. Circles are outliers (>1.5 interquartile range from the box, Teetor, 2011).

$\mathrm{N}=170-171$ for the macro-nutrients, $\mathrm{N}=73-76$ for the metals. The degrees of freedom are pooled and depend sample variances.

The figures are made using the software package $\mathrm{R}$.

\section{Table captions}

Table 1: ICPMS information on reference sample analyses and detection limits.

Table 1a: Concentrations with standard deviations and number of analyses of standard reference samples (GSP and SAFeD1) and in-house reference water (NADW, North Atlantic Deep Water). Our in-house reference water and the intercomparison exercise confirm accuracy of our Fe measurements although Fe determined in GSP and SAFe D1 are $0.1 \mathrm{nM}$ too high. We suspect that the particular reference bottles were slightly contaminated for Fe.

Table 1b: Blank and limit of detection concentrations in pM

Table 2: Endmember values used for the N/P-based four component mass-balance calculations. Numbers given in parentheses are the estimated uncertainties related to each endmember value. Analytical errors are all considerably smaller.

\section{References:}

Aagaard, K., 1980. On the deep circulation in the Arctic Ocean. DSR 27, 251-268.

Aagaard, K., Swift, J.H., Carmack, E.C., 1985. Thermohaline circulation in the Arctic Mediterranean Seas. J. Geophys. Res. 90, 4833-4846.

Aagaard, K., Carmack, E.C.,1989. The Role of Sea Ice and Other Fresh Water in the Arctic Circulation. J Geophys. Res., 94, C10, 14485-14498.

Alkire, M. B., Morison, J., \& Andersen, R., 2015. Variability in the meteoric water, sea- ice melt, and Pacific water contributions to the central Arctic Ocean, 2000-2014. Journal of Geophysical Research, Oceans, 120, 1573-1598. https://doi.org/10.1002/2014JC010023

Amon, R.M.W., Rinehart, A.J., Duan, S., Louchouarn, P., Prokushkin, A., Guggenberger, G., Bauch, D., Stedmon, C., Raymond, P.A., Holmes, R.M., McClelland, J.W., Peterson, 
B.J., Walker, S.A., Zhulidov, A.V., 2012. Dissolved organic matter sources in large Arctic rivers. Geochimica et Cosmochimica Acta 94, 217-237. https://doi.org/10.1016/j.gca.2012.07.015

Anderson, R. F., Bacon, M. P., \& Brewer, P. G., 1983. Removal of 230Th and 231Pa from the open ocean. Earth and Planetary Science Letters, 62, 7-23.

Anderson L. G., Björk G., Holby O., Jones E. P., Kattner G., Koltermann K. P., Liljeblad B., Lindegren R., Rudels B., Swift J. H., 1994. Water masses and circulation in the Eurasian Basin: results from the Oden 91 expedition. J. Geophys. Res. 99(C2), 32733283.

Anderson, L.G., Björk, G., Holby, O., Jutterström, S., Mörth, C.M., O'Regan, M., Pearce, C., Semiletov, I., Stranne, C., Stöven, T., Tanhua, T., Ulfsbo, A., Jakobsson, M., 2017. Shelf-Basin interaction along the East Siberian Sea. Ocean Sci. 13, 349-363.

Arrigo, K. R., G. L. van Dijken, 2011. Secular trends in Arctic Ocean net primary production, J. Geophys. Res.,116, C09011, doi:10.1029/2011JC007151.

Arrigo, K. R., Matrai, P. A., van Dijken, G. L., 2011. Primary productivity in the Arctic Ocean: Impacts of complex optical properties and subsurface chlorophyll maxima on large-scale estimates. Journal of Geophysical Research, 116, C11022. https://doi.org/10.1029/2011JC007273

Arrigo, K. R., van Dijken, G. L., 2015. Continued increases in Arctic Ocean primary production. Progress in Oceanography, 136(C), 60-70. https://doi.org/10.1016/j.pocean.2015.05.002

Arrigo, K. R., van Dijken, G. L., \& Pabi, S., 2008. Impact of a shrinking Arctic ice cover on marine primary production. Geophysical Research Letters, 35, L19603. https://doi.org/10.1029/2008GL035028

Bacon, M.P., Huh, C.-A., Moore, R.M., 1989. Vertical profiles of some natural radionuclides over the Alpha Ridge, Arctic Ocean. Earth and Planetary Science Letters 95, 15-22.

Baker, E. T., Edmonds, H. N., Michael, P. J., Bach, W., Dick, H. J. B., Snow, J. E., et al., 2004. Hydrothermal venting in magma deserts: the ultraslow-spreading Gakkel and Southwest Indian Ridges. Geochem. Geophys. Geosyst. 5, 1-29. doi: 10.1029/2004GC000712

Bauch, D., Rutgers van der Loeff, M., Andersen, N., Torres-Valdes, S., Bakker, K. \& Abrahamsen, E. P., 2011. Origin of freshwater and polynya water in the Arctic Ocean halocline in summer 2007, Progress in Oceanography, 91, 482-495, doi:10.1016/j.pocean.2011.07.017.

This article is protected by copyright. All rights reserved. 
Bauch, D., Schlosser, P. \& Fairbanks, R. F., 1995. Freshwater balance and the sources of deep and bottom waters in the Arctic Ocean inferred from the distribution of $\mathrm{H}_{2}{ }^{18} \mathrm{O}$, Progress in Oceanography, 35, 53-80.

Benner, R., Louchouarn, P., \& Amon, R. M. W., 2005. Terrigenous dissolved organic matter in the Arctic Ocean and its transport to surface and deep waters of the North Atlantic. Global Biogeochemical Cycles, 19, GB2025. https://doi.org/10.1029/2004GB002398

Biller, D. V., Bruland, K. W., 2012. Analysis of Mn, Fe, Co, Ni, Cu, Zn, Cd, and Pb in seawater using the Nobias-chelate PA1 resin and magnetic sector inductively coupled plasma mass spectrometry (ICP-MS). Mar. Chem., 130-131, 12-20.

https://doi.org/10.1016/j.marchem.2011.12.001

Björk, G., Jakobsson, M., Assmann, K., Andersson, L.G., Nilsson, J., Stranne, C., Mayer, L., 2018. Bathymetry and oceanic flow structure at two deep passages crossing the Lomonosov Ridge. Ocean Sci., 14, 1-13, https://doi.org/10.5194/os-14-1-2018.

Bown, J., M. Boye, and D. M. Nelson (2012), New insights on the role of organic speciation in the biogeochemical cycle of dissolved cobalt in the southeastern Atlantic and the Southern Ocean, Biogeosciences, 9, 2719-2736.

Bown, J., Laan, P., Ossebaar, S., Bakker, K., Rozema, P., de Baar, H.J.W., 2017. Bioactive trace metal time series during Austral summer in Ryder Bay, Western Antarctic Peninsula. DSR II, 139, 103-119.

Bruland, K. W., Middag, R., \& Lohan, M. C., 2014. 8.2 - Controls of trace metals in seawater A2 - Holland, Heinrich D. In K. K. Turekian (Ed.), Treatise on geochemistry, (2nd ed. pp. 19-51). Oxford, Elsevier. https://doi.org/10.1016/B978-0-08-095975-7.00602-1

Bucciarelli, E., Blain, S., Tréguer, P., 2001. Iron and manganese in the wake of the Kerguelen Islands (Southern Ocean). Mar. Chem. 73, 21-36.

Bullard, J. E., 2017. The distribution and biogeochemical importance of high latitude dust in the Arctic and Southern Ocean-Antarctic regions, J. Geophys. Res. Atmos., 122, 3098-3103, doi:10.1002/ 2016JD026363.

Bundy, R.M., Tagliabue, A., Hawco, N.J., Morton, P.L., Twining, B.S., Hatta, M., Noble, A.E., Cape, M.R., John, S.G., Cullen, J.T., Saito, M.A., 2020. Elevated sources of cobalt in the Arctic Ocean. Biogeosciences 17, 4745-4767. doi.org/10.5194/bg-174745-2020

Carmack, E., Polyakov, I., Padman,L., Fer, I., Hunke,E., Hutchings, J., Jackson, J., Kelley, D., Kwok, R., Layton, C., Melling, H., Perovich, D., Persson, O., Ruddick, B., Timmermans, M.-L., Toole, J., Ross, T., Vavrus, S., Winsor, P., 2015. Towards

This article is protected by copyright. All rights reserved. 
quantifying the increasing role of oceanic heat in sea ice loss in the new Arctic, Bull. Am. Meteorol. Soc., doi:10.1175/BAMS-D-13-00177.1.

Carmack, E. C., Yamamoto- Kawai, M., Haine, T. W. N., Bacon, S., Bluhm, B. A., Lique, C., et al. (2016). Freshwater and its role in the Arctic

marine system: Sources, disposition, storage, export, and physical and biogeochemical consequences in the Arctic and global oceans.

Journal of Geophysical Research: Biogeosciences, 121, 675-717. https://doi.org/10.1002/2015JG003140

Casacuberta, N., Masqué, P., Henderson, G., Rutgers van der Loeff, M., Bauch, D., Vockenhuber, C., et al., 2016. First 236U data from the Arctic Ocean and use of 236U/238U and 129I/236U as a new dual tracer. Earth and Planetary Science Letters, $440,127-134$.

Casacuberta, N., Christl, M., Vockenhuber, C., Wefing, A.-M., Wacker, L., Masqué, P., Synal, H.-A., Rutgers van der Loeff, M., 2018. Tracing the Three Atlantic Branches Entering the Arctic Ocean With 129I and 236U. Journal of Geophysical Research: Oceans 123, 6909-6921.

Charette, M., Kipp, L.E., Jensen, L.T., Dabrowski, J.S., Whitmore, L.M., Fitzsimmons, J.N. et al.,2020. The Transpolar Drift as a Source of Riverine and Shelf-Derived Trace Elements to the Central Arctic Ocean. JGR-Oceans https://doi.org/10.1029/2019JC015920

Cid, A. P., Nakatsuka, S., Sohrin, Y., 2012. Stoichiometry among bioactive trace metals in the Chukchi and Beaufort Seas. Journal of Oceanography, 68(6), 985-1001.

Cowen J. P. and Bruland K. W.,1985. Metal deposits associated with bacteria: implications for Fe and Mn marine biogeochemistry. Deep Sea Res. Part A Oceanogr. Res. Pap. 32, 253-272.

Dai, M.H., Martin, J.M., 1995. First data on trace metal level and behaviour in two major Arctic river-estuarine systems (Ob and Yenisey) and in the adjacent Kara Sea, Russia. Earth Planet. Sci. Lett. 131, 127-141.

De Baar, H. J. W., La Roche, J., 2003. "Metals in the oceans: Evolution, biology and global change," in Marine Scientific Frontiers for Europe, eds F. Lamy and G. Wefer (New York, NY: Springer),79-105.

de Baar, H.J.W., Timmermans, K.R., Laan, P., De Porto, H.H., Ober, S., Blom, J.J., Bakker, M.C., Schilling, J., Sarthou, G., Smit, M.G., Klunder, M., Baar, H.J.W. De, Timmermans, K.R., Laan, P., Porto, H.H. De, Ober, S., 2008. Titan: A new facility for 
ultraclean sampling of trace elements and isotopes in the deep oceans in the international Geotraces program. Mar. Chem. 111, 4-21.

Dittmar, T., Kattner, G. (2003): The biogeochemistry of the river and shelf ecosystem of the Arctic Ocean: a review.- Mar. Chem. 83: 103-20, doi. org/10.1016/s03044203(03)00105-1

Dickson B., Meincke J., Rhines P., 2008. Arctic-Subarctic Ocean Fluxes: Defining the Role of the Northern Seas in Climate. Chapter 2 in: Dickson R.R., Meincke J., Rhines P. (eds) Arctic-Subarctic Ocean Fluxes. Springer, Dordrecht. https://doi.org/10.1007/978-1-4020-6774-7_1

Dittmar, T., Kattner, G., 2003. The biogeochemistry of the river and shelf ecosystem of the Arctic Ocean: A review, Mar. Chem., 83, 103-120.Dulaquais, G., Planquette, H., L'Helguen, S., Rijkenberg, M. J. A., Boye, M., 2017.The biogeochemistry of cobalt in the Mediterranean Sea, Global Biogeochem. Cycles, 31, 377-399, doi:10.1002/ 2016 GB005478.

Dulaquais, G., Boye, M., Middag, R., Owens, S., Puigcorbe, V., Buesseler, K., Masqué, P., de Baar, H. J.W., Carton, X., 2014. Contrasting biogeochemical cycles of cobalt in the surface western Atlantic Ocean, Global Biogeochem. Cycles, 28, 1387-1412, doi:10.1002/ 2014GB004903.

Edmonds, H.N., Moran, S.B., Hoff, J.A., Smith, J.N., Edwards, R.L., 1998. Protactinium-231 and Thorium-230 abundances and high scavenging rates in the western Arctic Ocean. Science 280, 405-407.

Edmonds, H. N., Michael, P. J., Baker, E. T., Connelly, D. P., Snow, J. E., Langmuir, C. H., Dick, H.J.B., Mühe, R., German, C.R., Graham, D.W., 2003. Discovery of abundant hydrothermal venting on the ultraslow-spreading Gakkel ridge in the Arctic Ocean. Nature 421, 252-256. doi: 10.1038/nature01351

Edmonds, H.N., Moran, S.B., Cheng, H., Edwards, R.L., 2004. ${ }^{230} \mathrm{Th}$ and ${ }^{231} \mathrm{~Pa}$ in the Arctic Ocean: implications for particle fluxes and basin-scale $\mathrm{Th} / \mathrm{Pa}$ fractionation. Earth and Planetary Science Letters 227, 155-167.

Ekwurzel, B., Schlosser, P., Mortlock, R.A., Fairbanks, R.G., Swift, J.H., 2001. River runoff, sea ice meltwater, and Pacific water distribution and mean residence times in the Arctic Ocean. Journal of Geophysical Research 106 (C5), 9075-9092.

Garnier, J.-M. Martin, J.-M. Mouchel, J.-M., Sioud, I., 1996. Partitioning of trace metals between the dissolved and particulate phases and particulate surface reactivity in the Lena River estuary and the Laptev Sea Russia. Marine Chemistry 53 (1996) 269-283

This article is protected by copyright. All rights reserved. 
Gdaniec, S., Roy-Barman, M., Levier, M., Valk, O., Rutgers van der Loeff, M., Foliot, L., Dapoigny, A., Missiaen, L., Mörth, C.-M., Andersson, P.S., 2020. 231Pa and 230Th in the Arctic Ocean: Implications for boundary scavenging and 231Pa/230Th fractionation in the Eurasian Basin Chem geology 532, 2020, 119380

Gerringa, L.J.A., Rijkenberg, M.J.A., Schoemann, V., Laan, P., de Baar, H.J.W., 2015. Organic complexation of iron in the West Atlantic Ocean. Mar Chem. 177:434-446. .doi.org/10.1016/j.marchem.2015.04.007

Gerringa, L.J.A., Slagter, H.A., Bown, J., van Haren, H., Laan, P., de Baar, H.J.W., Rijkenberg, M.J.A., 2017. Dissolved Fe and Fe-binding dissolved organic ligands in the Mediterranean Sea. Marine Chemistry, 194: 100-113. http://dx.doi.org/10.1016/j.marchem.2017.05.012

Gerringa, L.J.A., Alderkamp, A-C., van Dijken, G., Laan, P., Middag, R., Arrigo, K.R., 2020. Dissolved trace metals in the Ross Sea. Front. Mar. Sci. 7:577098. doi: 10.3389/fmars.2020.577098

Gordienko, P.A., Laktionov, A.F., 1969. Circulation and physics of the Arctic basin waters. In: Gordon, A.L., Baker, F.W.G. (Eds.), Oceanography: Annals of the International Geophysical Year, vol. 46. Pergamon Press, London, pp. 94-112.

Grasshoff, K., 1983. “Determination of nitrate,” in Methods of Seawater Analysis, eds K. Grasshoff, M. Erhardt, and K. Kremling (Weinheim: Verlag Chemie), 143-187.

Gregor, D.J., Loeng, H., Barrie, L., 1998. The influence of physical and chemical processes on contaminant transport into and within the Arctic. In: Arctic Monitoring and Assessment Report: Arctic Pollution Issues.Grenier, M., François, R., Soon, M., Rutgers van der Loeff, M., Yu, X., Valk, O., Not, C., Moran, S.B., Edwards, R.L., Lu, Y., LePore, K., Allen, S.E., 2019. Changes in circulation and particle scavenging in the Amerasian basin of the Arctic Ocean over the last three decades inferred from the water column distribution of geochemical tracers. Journal of Geophysical Research: Oceans, 124, 9338-9363. https://doi.org/10.1029/2019JC015265

Gordeev, V. V., 2000. River Input of Water, Sediment, Major Ions, Nutrients and Trace Metals from Russian Territory to the Arctic Ocean. The Freshwater Budget of the Arctic Ocean pp 297-322. Part of the NATO Science Series book series (ASEN2, volume 70)

Guay, C.K.H., Zhulidov, A.V., Robarts, R.D., Zhulidov, D.A., Gurtovaya, T.Y., Holmes, R.M., Headley, J.V., 2010. Measurements of $\mathrm{Cd}, \mathrm{Cu}, \mathrm{Pb}$ and $\mathrm{Zn}$ in the lower reaches

This article is protected by copyright. All rights reserved. 
of major Eurasian arctic rivers using trace metal clean techniques. Environmental Pollution 158 (2010) 624-630

Guieu, C., Huang, W.W., Martin, J.M., Yong, Y.Y., 1996. Outflow of trace metals into the Laptev Sea by the Lena River. Mar. Chem. 53, 255-267.

Hansen B. Østerhus, S.,Turrell, W.R., Jónsson, S., Valdimarsson, H., Hátún , H., Malskær Olsen, S., 2008 The Inflow of Atlantic Water, Heat, and Salt to the Nordic Seas Across the Greenland-Scotland Ridge. In: Dickson R.R., Meincke J., Rhines P. (eds) Arctic-Subarctic Ocean Fluxes. Springer, Dordrecht. https://doi.org/10.1007/978-1-4020-6774-7_2

Hendry, K. R., Rickaby, R. E. M., de Hoog, J. C. M., Weston, K., and Rehkämper, M. (2008). Cadmium and phosphate in coastal Antarctic seawater: implications for Southern Ocean nutrient cycling Marine Chemistry. Mar. Chem. 112, 149-157. doi: 10.1016/j.marchem.2008.09.004

Hölemann, J.A., Schirmacher, M., Prange, A., 2005. Seasonal variability of trace metals in the Lena River and the southeastern Laptev Sea: Impact of the spring freshet. Global and Planetary Change 48, 112-125.

IPCC, 2014. "Climate Change 2014: Synthesis Report. Contribution of Working Groups I, II and III," in Fifth Assessment Report of the Intergovernmental Panel on Climate Change. Core Writing Team, eds R. K. Pachauri and L. A. Meyer (IPCC, Geneva), 151.

Ito, M., Ohshima, K. I., Fukamachi, Y., Hirano, D., Mahoney, A. R., Jones, J., et al. (2019). Favorable conditions for suspension freezing in an Arctic coastal polynya. Journal of Geophysical Research: Oceans, 124, 8701-8719. https://doi.org/10.1029/2019JC015536

Jackson, S., 2017. The Distribution of Dissolved cadmium in the Canadian Arctic Ocean. Master thesis from Victoria University of Wellington. https://dspace.library.uvic.ca/handle/1828/8920

Jensen L. T., Morton,P., Twining B. S., Heller, M.I., Hatta, M., Measures, C.I., John, S.,Zhang, R., Pinedo-Gonzalez, P., Sherrell, R.M., Fitzsimmons, J.N., 2020. A comparison of marine Fe and Mn cycling: U.S. GEOTRACES GN01 Western Arctic case study. Geochim., Cosmochim. A. 288: 138-160.

Jensen L. T., Wyatt N. J., Twining B. S., Rauschenberg S., Landing W. M., Sherrell R. M. Fitzsimmons J. N., 2019. Biogeochemical Cycling of Dissolved Zinc in the Western Arctic (Arctic GEOTRACES GN01). Global Biogeochem. Cycles 33, 343-369.

This article is protected by copyright. All rights reserved. 
Johnson, K.S., Gordon, R.M., Coale, K.H., 1997. What controls dissolved iron concentrations in the world ocean? Mar. Chem. 57, 137-161.

Jones, E.P., Anderson, L.G., 1986. On the origin of the chemical properties of the Arctic Ocean Halocline. J. Geophys. Res. 91, 10759-10767.

Jones, E. P., J. H. Swift, L. G. Anderson, M. Lipizer, G. Civitarese, K. K. Falkner, G. Kattner, and F. McLaughlin, 2003. Tracing Pacific water in the North Atlantic Ocean, J. Geophys. Res., 108(C4), 3116, doi:10.1029/2001JC001141.

Jones, E. P., Anderson, L. G., Jutterström, S., Mintrop, L. \& Swift, J. H., 2008. Pacific freshwater, river water and sea ice meltwater across Arctic Ocean basins: Results from the 2005 Beringia Expedition, J. Geophys. Res., 113, C08012, doi:10.1029/2007JC004124.

Kipp, L. E., Charette, M. A., Moore, W. S., Henderson, P. B., \& Rigor, I. G., 2018. Increased fluxes of shelf-derived materials to the central Arctic Ocean. Science Advances, 4(1), eaao1302. https://doi.org/10.1126/sciadv.aao1302

Klunder, M. B., Bauch, D., Laan, P., de Baar, H. J. W., van Heuven, S., Ober, S., 2012 a. Dissolved iron in the Arctic shelf seas and surface waters of the central Arctic Ocean: impact of Arctic river water and ice-melt. J. Geophys. Res. 117:C01027. doi: 10.1029/2011JC007133

Klunder, M. B., Laan, P., Middag, R., de Baar, H. J. W., Bakker, K., 2012b. Dissolved iron in the Arctic Ocean: important role of hydrothermal sources, shelf input and scavenging removal. J. Geophys. Res. 117:C04014. doi: 10.1029/2011JC007135

Karcher, M., Harms, I., Standring, W.J.F., Dowdall, M., Strand, P., 2010. On the potential for climate change impacts on marine anthropogenic radioactivity in the Arctic regions. Marine Pollution Bulletin 60 (2010) 1151-1159

Lagerström, M.E., Field, M.P., Séguret, M. Fischer, L., Hann, S., Sherrell, R.M., 2013. Automated on-line flow-injection ICP-MS determination of trace metals (Mn, Fe, Co, $\mathrm{Ni}, \mathrm{Cu}$ and $\mathrm{Zn}$ ) in open ocean seawater: Application to the GEOTRACES program Marine Chemistry 155, 71-80

Laglera, L.M., van den Berg, C.M.G., 2009. Evidence for geochemical control of iron by humic substances in seawater. Limnol. Oceanogr. 54,610-619

Laglera, L.M., Sukekava, C., Slagter, H.A., Downes, J., Aparicio-Gonzalez, A.' Gerringa, L.J.A., 2019. First direct evidence of humic substances controlling iron transport across the surface of the Arctic Ocean, Env. Sci. \& Techn., 53, 22, 13136-13145 DOI: 10.1021/acs.est.9b04240

This article is protected by copyright. All rights reserved. 
Lao, Y., Anderson, R.F. Broecker, W.S., 1992. Boundary scavenging and deep sea sediment dating: constraints from excess $230^{\mathrm{Th}}$ and $231 \mathrm{~Pa}$. Paleoceanography and paleoclimatology 7, 783-798.

Lane, T.W., Morel, F.M.M., 2000. A biological function for cadmium in marine di-atoms. Proc. Natl. Acad. Sci. USA97, 4627-4631.

Lane, T.W., Saito, M.A., George, G.N., Pickering, I.J., Prince, R.C., Morell, F.M.M., 2005. A cadmium enzyme from a marine diatom. Nature 435: 42, doi:10.1038/435042a

Laukert, G. Frank, M., Hathorne, E.C., Krumpen, T., Rabe, B., Bauch, D., Werner, K., Peeken, I., Kassens, H., 2017. Pathways of Siberian freshwater and sea ice in the Arctic Ocean traced with radiogenic neodymium isotopes and rare earth elements. Polarforschung 87, 3-13.

Lenth, R. V., 2016. "Least-Squares Means: The R Package lsmeans," Journal of Statistical Software, Foundation for Open Access Statistics, vol. 69(i01).

Lewis, K.M., Arntsen, A. E., Coupel, P., Joy- Warren, H., Lowry, K.E., Matsuoka, A., Mills, M.M., van Dijken, G.L., Selz, V., Arrigo, K. R., 2019. Photoacclimation of arctic ocean phytoplankton to shifting light and nutrient limitation. Limnol Oceanogr. 64, 284-301. doi: 10.1002/lno.11039

Lowry, K. E., Pickart, R. S., Selz, V., Mills, M. M., Pacini, A., Lewis, K. M., ... Arrigo, K. R. (2018). Under-ice phytoplankton blooms inhibited by spring convective mixing in refreezing leads. Journal of Geophysical Research: Oceans, 123, 90-109. https://doi.org/ 10.1002/2016JC012575

Macdonald, R.W., Carmack, E.C., Wallace, D.W.R., 1993. Tritium and radiocarbon dating of Canada basin deep waters. Science 259, 103-104.

Maslanik, J., Stroeve, J., Fowler, C., Emery, W., 2011. Distribution and trends in Arctic sea ice age through spring 2011, Geophys. Res. Lett., 38, L13502, doi:10.1029/2011GL047735.

Martin. J.M., Guan. D.M., Elbaz-Poulichet, F., Thomas, A.J., Gordeev, V.V., 1993. Preliminary assessment of the distribution of trace metal elements (As, $\mathrm{Cd}, \mathrm{Cu}$. Fe, $\mathrm{Ni}$, $\mathrm{Pb}$ and $\mathrm{Zn}$ ) in a pristine aquatic environment: The Lena river estuary (Russia). Mar. Chem., 43: 1S5-I99.Measures, C.I., 1999. The role of entrained sediments in sea ice in the distribution of aluminium and iron in the surface waters of the Arctic Ocean. Marine Chemistry 68 (1-2), 59-70.

Middag, R., de Baar, H.J.W., Laan, P., Bakker, K., 2009. Dissolved aluminium and the silicon cycle in the Arctic Ocean. Marine Chemistry 115, 176-195.

This article is protected by copyright. All rights reserved. 
Middag, R., de Baar, H. J. W., Laan, P., and Klunder, M. B., 2011. Fluvial and hydrothermal input of manganese into the Arctic Ocean. Geochim. Cosmochim. Acta 75, 23932408. doi: 10.1016/j.gca.2011.02.011.

Middag, R., Séférian, R., Conway, T.M., John, S.G., Bruland, K.W., de Baar, H.J.W., 2015. Intercomparison of dissolved trace elements at the Bermuda Atlantic Time Series station. Marine Chemistry, 177, Part 3, 476-489.

Middag, R., van Heuven, S. M. A. C., Bruland, K. W., and de Baar, H. J. W., 2018. The relationship between cadmium and phosphate in the Atlantic Ocean unravelled. Earth Plane. Sci. Lett. 492, 79-88. doi: 10.1016/j.eps1.2018.03.046

Millero F. J., Sotolongo S., Izaguirre M. (1987) The oxidation kinetics of Fe(II) in seawater. Geochim. Cosmochim. Acta 51, 793-801.

Moffett, J. W., Ho, J.: Oxidation of cobalt and manganese in seawater via a common microbially catalyzed pathway, Geochim. Cosmochim. Acta, 60(18), 3415-3424,1051 doi:10.1016/0016-7037(96)00176-7, 1996.

Moore, R., 1981. Oceanographic distributions of zinc, cadmium, copper and aluminium in waters of the central arctic. Geochim. Cosmochim. Acta, 45(12), 2475-2482. https://doi.org/10.1016/0016-7037(81)90099-5

Murphy, J., and Riley, J. P., 1962. A modified single solution method for the determination of phosphorous in natural waters. Anal. Chim. Acta 27, 31-36. doi: 10.1016/S00032670(00)88444-5

Newton, R., Schlosser, P., Mortlock, R., Swift, J., \& MacDonald, R. 2013. Canadian Basin freshwater sources and changes: Results from the 2005 Arctic Ocean section. Journal of Geophysical Research, Oceans, 118, 2133-2154. https://doi.org/10.1002/jgrc.20101

Östlund, H.G., Hut, G., 1984. Arctic Ocean water mass balance from isotope data. Journal of Geophysical Research 89 (NC4), 6373-6381.

Paffrath, R., Laukert, G., Bauch, D., Rutgers van der Loeff, M., Pahnke, K., 2021. Separating individual contributions of major Siberian rivers in the Transpolar Drift of the Arctic Ocean. Scientific Reports, 11:8216. https://doi.org/10.1038/s41598-021-86948-y

Pfirman, S.L., Kögeler, J.W., Rigor, I., 1997. Potential for rapid transport of contaminants from the Kara Sea. Sci Total Environm., 2020, 11-122.

Polyakov, I. V., Pnyushkov, A. V., Alkire, M., Ashik, I. M., Baumann, T., Carmack, E., et al. (2017). Greater role for Atlantic inflows on sea- ice loss in the Eurasian Basin of the Arctic Ocean. Science, 356(6335), 285-291. https://doi.org/10.1126/science.aai8204

This article is protected by copyright. All rights reserved. 
Price, N.M., Morel, F.M.M., 1990. Cadmium and cobalt substitution for zinc in a marine diatom. Nature 344, 658-660

Quay, P., Cullen, J., Landing, W., Morton, P., 2015, Processes controlling the distributions of Cd and PO4 in the ocean, Global Biogeochem. Cycles, 29, 830-841, doi:10.1002/2014GB004998.

R Development Core Team, R., 2011. R: A language and environment for statistical computing. $\mathrm{R}$ foundation for statistical computing, Vienna, Austria.

Raiswell, R., and Anderson, T.F., 2005, Reactive iron enrichment in sediments deposited beneath euxinic bottom waters: constraints on supply by shelf re-cycling, in McDonald, I. Boyce, A.J., Butler, I, Herrington, R.J., and Polya, D., editors, Mineral Deposits and Earth Evolution: Geological Society of London Special Publication, v. 218, p. 179-194.

Rijkenberg, M.J.A., de Baar, H.J.W., Bakker, K., Gerringa, L.J.A., Keijzer, E., Laan, M., Laan, P., Middag, R., Ober, S., van Ooijen, J., Ossebaar, S., van Weerlee, E.M., Smit, M.G., 2015. "PRISTINE", a new high volume sampler for ultraclean sampling of trace metals and isotopes. Mar. Chem. 177, 501-509.

Rijkenberg, M.J.A., Slagter, H.A., Rutgers van der Loeff, M., van Ooijen, J., Gerringa, L.J.A., 2018. Sources of dissolved Fe in the deep and upper Arctic Ocean with a focus on Fe limitation in the Nansen Basin. Front. Mar. Sci. 5:88. doi: 10.3389/fmars.2018.00088

R Core Team (2020). R: A language and environment for statistical computing. R Foundation for Statistical Computing, Vienna, Austria. URL https://www.R-project.org/.

Roy-Barman, M. 2009. Modelling the effect of boundary scavenging on Thorium and Protactinium profiles in the ocean. Biogeosciences, European Geosciences Union, 2009, 6, pp.3091 - 3107. Doi:org/10.5194/bg-6-3091/2009/

Rudels, B., 1986. The $\Theta-S$ relations in the northern seas: implications for the deep circulation. Polar Research 4, 133-159.

Rudels, B., 2009. Arctic Ocean Circulation. Encyclopedia of Ocean Sciences, 211-225. https://doi.org/10.1016/B978-012374473-9.00601-9

Rudels, B., 2012. Arctic Ocean circulation and variability - advection and external forcing encounter constraints and local processes Ocean Sci., 8, 261-286. doi:10.5194/os-8261-2012.

Rudels, B., 2015. Arctic Ocean circulation, processes and water masses: a description of observations and ideas with focus on the period prior to the international polar year 2007-2009. Prog. Oceanogr. 132, 22-67.doi: 10.1016/j.pocean.2013.11.006

This article is protected by copyright. All rights reserved. 
Rudels, B., Muench, R.D., Gunn, J., Schauer, U., Friedrich, H.J., 2000. Evolution of the Arctic Ocean boundary current north of the Siberian Shelves. Journal of Marine Systems 25 (1), 77-99.

Rudels, B., Anderson, L., Eriksson, P., Fahrbach, E., Jokobsson, M., Jones, E. P., Melling, H., Prinsenberg, S., Schauer, U., and Yao, T., 2011. Observation in the Ocean. Chapter 4 in: Arctic Climate Change: The ACSYS decade and beyond, edited by: Lemke, P. and Jacobi, H.-W., 117-198, Springer, Heidelberg.

Rutgers van der Loeff, M., Kipp, L., Charette, M. A., Moore, W. S., Black, E., Stimac, I., et al., 2018. Radium isotopes across the Arctic Ocean show time scales of water mass ventilation and increasing shelf inputs. Journal of Geophysical Research: Oceans, 123, 4853-4873. https://doi.org/10.1029/2018JC013888

Saito, M. A., Moffett, J. W., 2001. Complexation of cobalt by natural organic ligands in the Sargasso Sea as determined by a new high sensitivity electrochemical cobalt speciation method suitable for open ocean work, Mar. Chem., 75(1), 49-68.

Schlitzer, R., Ocean Data View, https://odv.awi.de, 2020

Schlitzer, R., Anderson, R. F., Masferrer Dodas, E, et al., 2018 The GEOTRACES Intermediate Data Product 2017, Chem. Geol. https://doi.org/10.1016/j.chemgeo.2018.05.040.

Schlosser, P., Kromer, B., Östlund, G., Ekwurzel, B., Bönisch, G., Loosli, H.H., Purtschert, R., 1994. On the 14C and 39Ar Distribution in the Central Arctic Ocean: Implications for Deep Water Formation. Radiocarbon 36, 327-343.

Schlosser, P., Kromer, B., Ekwurzel, B., Bbnisch, G, McNichol, A., Schneider, R., von Reden, K., Östlund, H.G., Swift, J.H..,1997. The first trans-Arctic 14C section: comparison of the mean ages of the deep waters in the Eurasian and Canadian basins of the Arctic Ocean. Nuclear Instruments and Methods in Physics Research B I23 (1997) 43 I-437

Schlosser, P. Bönisch, G., Kromer, B., Münnich, K.O., Koltermann, K., P.,1990. Ventilation Rates of the Waters in the Nansen Basin of the Arctic Ocean Derived From a Multitracer Approach JGR. 95, NO. C3, PAGES 3265-3272. DOI: 10.1029/JC095iC03p03265

Scholten, J.C., Rutgers van der Loeff, M.M., Michel, A., 1995. Distribution of ${ }^{230} \mathrm{Th}$ and ${ }^{231} \mathrm{~Pa}$ in the water column in relation to the ventilation of the deep Arctic Basins. Deep-Sea Res. II. 42, 1519-1531.

This article is protected by copyright. All rights reserved. 
Sholkovitz, E. R.; Copland, D., 1981. The coagulation, solubility and adsorption properties of $\mathrm{Fe}, \mathrm{Mn}, \mathrm{Cu}, \mathrm{Ni}, \mathrm{Cd}, \mathrm{Co}$ and humic acids in a river water. Geochim. Cosmochim. Acta, $45,181-189$.

Serreze, M. C., Stroeve, J., 2015. Arctic sea ice trends, variability and implications for seasonal ice forecasting. Philos. Trans. R. Soc. A Math. Phys. Eng. Sci. 373:20140159. doi: 10.1098/rsta.2014.0159.

Serreze, M. C., Stroeve, J., Barrett, A. P., Boisvert, L. N., 2016. Summer atmospheric circulation anomalies over the Arctic Ocean and their influences on September sea ice extent: a cautionary tale. J. Geophys. Res. Atmos. 121:485. doi: 10.1002/2016JD025161.

Seyitmuhammedov, K., 2020. Biogeochemical cycling of trace metals in the shelf regions: importance of cross-shelf exchange. $\mathrm{PhD}$ thesis Departmen of Chemistry. Dunedin, New Zealand, University of Otago.

Slagter, H.A., Reader, H.E., Rijkenberg, M.J.A., Rutgers van der Loeff, M., de Baar, H.J.W., Gerringa, L.J.A..,2017. Fe speciation is related to terrestrial dissolved organic matter in the Arctic Ocean. Marine Chemistry 197 (2017) 11-25. http://dx.doi.org/10.1016/j.marchem.2017.10.005

Slagter, H.A., Laglera, L.M., Sukekava, C., Gerringa, L.J.A., 2019. Fe-binding organic ligands in the humic-rich TransPolar Drift in the surface Arctic Ocean using multiple voltammetric methods. Journal of Geophysical Research: Oceans. DOI: 10.1029/2018JC014576

Smethie, W.M., 2017. Pangaea database: doi:10.1594/PANGAEA.872956

Smethie, W.M., Newton, R., Schlosser, P., Pasqualini, A., 2019. Relic Water in the Deep Arctic Ocean, Goldschmidt, Barcelona.

Smith, J.N., Karcher, M., Casacuberta, N., Williams, W.J., Kenna, T., Smethie Jr, W.M., 2021. A changing Arctic Ocean: How measured and modeled 129I distributions indicate fundamental shifts in circulation between 1994 and 2015. JGR Oceans. https://doi.org/10.1029/2020JC016740.

Stedmon, C.A., Amon, R.M.W., Rinehart, A.J., Walker, S.A., 2011. The supply and characteristics of colored dissolved organic matter (CDOM) in the Arctic Ocean: Pan Arctic trends and differences Marine Chemistry 124 (2011) 108-118. DOI:10.1016/j.marchem.2010.12.007

Stranne, C., Sohn, R.A., Lijebladh, B, Nakamura, K., 2010. Analysis and modeling of hydrothermal plume data acquiredfrom the $85^{\circ} \mathrm{E}$ segment of the Gakkel Ridge. JGR, 115, C06028, doi:10.1029/2009JC005776, 2010

This article is protected by copyright. All rights reserved. 
Strickland, J. D. H., and Parsons, T. R. (1972). A Practical Handbook of Seawater Analysis. Ottawa: Fisheries Research Board of Canada.

Stumm, W., Morgan, J., 1981. Aquatic Chemistry, 780, J. Wiley \& Sons.

Sukekava, C. Downes, J., Slagter, H.A., Gerringa, L.J.A., Laglera, L.M., 2018. Determination of the contribution of humic substances to iron complexation in seawater by catalytic cathodic stripping voltammetry. Talanta 189, 359-364. https://doi.org/10.1016/j.talanta.2018.07.021

Sunda W. G., 2012 Feedback Interactions between Trace Metal Nutrients and Phytoplankton in the Ocean. Frontiers in Microbiology. 3: 204. DOI: 10.3389/fmicb.2012.00204

Sunda, W. G. and Huntsman, S. A. 1988.: Effect of sunlight on redox cycles of manganese in the southwestern Sargasso Sea, Deep Sea Res. Part A. Oceanogr. Res. Pap., 35(8), 1297-1317.

Tanhua, T., Jones, E.P., Jeansson, E., Jutterström, S., Jr., W.M.S., Wallace, D.W.R., Anderson, L.G., 2009. Ventilation of the Arctic Ocean: Mean ages and inventories of anthropogenic CO2 and CFC-11. J. Geophys. Res. 114, C01002, doi:01010.01029/02008JC004868.

Teetor, P., 2011. R Cookbook, O'Reilly Media, Inc.

Thuróczy, C.-E., Gerringa, L.J.A., Klunder, M., Laan, P., le Guitton, M., de Baar, H.J.W., 2011. Distinct trends in the speciation of iron between the shelf seas and the deep basins of the Arctic Ocean. J. Geophys. Res., VOL. 116, C10009, doi: 10.1029/2010JC006835.

Timmermans, M.-L., Garrett, C., 2006. Evolution of the Deep Water in the Canadian Basin in the Arctic Ocean. Journal of Physical Oceanography 36, 866-874.

Timmermans, M.-L., Garrett, C., Carmack, E., 2003. The thermohaline structure and evolution of the deep waters in the Canada Basin, Arctic Ocean. Deep Sea Research Part I: Oceanographic Research Papers 50, 1305-1321.

Valk, O., Rutgers van der Loeff, M.M., Geibert, W., Gdaniec, S., Rijkenberg, M.J.A., Moran, S.B., Lepore, K., Edwards, R.L., Lu, Y., Puigcorbé, V., 2018. Importance of hydrothermal vents in scavenging removal of ${ }^{230} \mathrm{Th}$ in the Nansen Basin Geophys. Res. Lett., pp. 1-10, 10.1029/2018GL079829.

Valk, O., Rutgers van der Loeff, M.M., Geibert, W., Gdaniec, S., Moran, S.B., Lepore, K., Edwards, R.L., Lu, Y., Puigcorbé, V, Casacuberta, N., Paffrath, R., Smethie, W., RoyBarman, M., 2020. Decrease in 230Th in the Amundsen Basin since 2007: far-field 
effect of increased scavenging on the shelf? Ocean Sci., 16, 221-234.

https://doi.org/10.5194/os-16-221-2020

Whitby, H., van den Berg, C.M.G., 2015. Evidence for copper-binding humic substances in seawater. Mar. Chem., 282-290

Whitmore, L. M., P. L. Morton, B. S. Twining, and A. M. Shiller (2019), Vanadium cycling in the Western Arctic Ocean is influenced by shelf-basin connectivity, Marine Chemistry, 216, 103701.

Williford, T., Amon, R.M.W., Benner, R., Kaiser, K., Bauch, D. Stedmon, C., Yan, G., Walker, S.A., Rutgers van der Loeff, M., Klunder, M., 2021. Insights into the origins, molecular characteristics and distribution of iron-binding ligands in the Arctic Ocean. Marine Chemistry 231 (2021) 103936

Yamamoto-Kawai, M., McLaughlin, F. A., Carmack, E. C., Nishino, S. \& Shimada, K., 2008. Freshwater budget of the Canada Basin, Arctic Ocean, from salinity, d180, and nutrients, Journal of Geophysical Research, 113(C01007), doi:10.1029/2006JC003858.

Yang, R., Su, H., Qu, S., Wang, X., 2017. Capacity of humic substances to complex with iron at different salinities in the Yangtze River estuary and East China Sea. Scientific Reports, 7: 1381. DOI:10.1038/s41598-017-01533-6

Yeats, P. A. (1988). Manganese, nickel, zinc and cadmium distributions at the Fram 3 and Cesar ice camps in the Arctic Ocean. Oceanologica Acta, 11(4), 383-388.

Yeats P. A. and Westerlund S. (1991) Trace-metal distributions at an Arctic-Ocean Ice Island. Mar. Chem. 33(3), 261-277.

Xu, Y., Feng, L., Jeffrey, P.D., Shi, Y., Morel, F.M.M., 2008. Structure and metal exchange in the cadmium carbonic anhydrase of marine diatoms. Nature 452, 56-61.

Zhang, R., L. T. Jensen, J. N. Fitzsimmons, R. M. Sherrell, and S. John (2019), Dissolved cadmium and cadmium stable isotopes in the western Arctic Ocean, Geochimica et Cosmochimica Acta, 258, 258-273.

This article is protected by copyright. All rights reserved. 


\section{TABLES}

Table 1: ICPMS information on reference sample analyses and detection limits.

Table 1a: Concentrations with standard deviations and number of analyses of standard reference samples (GSP and SAFeD1) and in-house reference water (NADW, North Atlantic Deep Water). Our in-house reference water and the intercomparison exercise confirm accuracy of our Fe measurements although Fe determined in GSP and SAFe D1 are $0.1 \mathrm{nM}$ too high. We suspect that the particular reference bottles were slightly contaminated for Fe.

\begin{tabular}{|c|c|c|c|c|c|c|c|}
\hline \multicolumn{8}{|c|}{ GSP } \\
\hline \multicolumn{8}{|c|}{ Determined } \\
\hline$\# 227$ & Cd & Co & $\mathrm{Cu}$ & $\mathbf{F e}$ & Mn & $\mathbf{N i}$ & $\mathbf{Z n}$ \\
\hline & $\mathbf{n M}$ & pM & $\mathbf{n M}$ & $\mathbf{n M}$ & $\mathbf{n M}$ & $\mathbf{n M}$ & $\mathbf{n M}$ \\
\hline Mean & 0.0015 & 8 & 0.568 & 0.25 & 0.761 & 2.542 & 0.067 \\
\hline$\pm \mathrm{SD}$ & 0.0001 & 0.4 & 0.004 & 0.06 & 0.001 & 0.024 & 0.005 \\
\hline $\mathrm{n}$ & 3 & 3 & 3 & 3 & 3 & 3 & 3 \\
\hline \multicolumn{8}{|c|}{ Consensus } \\
\hline & Cd & & $\mathbf{C u}$ & $\mathbf{F e}$ & Mn & $\mathbf{N i}$ & $\mathbf{Z n}$ \\
\hline & $\mathbf{n M}$ & & $\mathbf{n M}$ & $\mathbf{n M}$ & $\mathbf{n M}$ & $\mathbf{n M}$ & $\mathbf{n M}$ \\
\hline Mean & 0.002 & - & 0.574 & 0.155 & 0.778 & 2.595 & 0.030 \\
\hline$\pm \mathrm{SD}$ & 0.002 & - & 0.053 & 0.045 & 0.034 & 0.100 & 0.052 \\
\hline $\mathrm{n}$ & 4 & - & 9 & 11 & 9 & 11 & 10 \\
\hline \multicolumn{8}{|c|}{ NADW-In house reference material } \\
\hline & Cd & Co & $\mathbf{C u}$ & $\mathbf{F e}$ & Mn & $\mathbf{N i}$ & $\mathbf{Z n}$ \\
\hline Mean & 0.18 & 53 & 1.323 & 0.534 & 0.426 & 3.58 & 3.236 \\
\hline$\pm \mathrm{SD}$ & 0.005 & 2 & 0.039 & 0.023 & 0.010 & 0.1 & 0.078 \\
\hline $\mathrm{n}$ & 18 & 18 & 18 & 18 & 18 & 18 & 13 \\
\hline \multicolumn{8}{|c|}{ SAFe-D1 } \\
\hline \multicolumn{8}{|c|}{ Determined } \\
\hline \#599 & Cd & Co & $\mathbf{C u}$ & Fe & Mn & $\mathbf{N i}$ & $\mathbf{Z n}$ \\
\hline Mean & 1.013 & 43 & 2.044 & 0.824 & 0.409 & 8.758 & 7.537 \\
\hline$\pm \mathrm{SD}$ & 0.007 & 1 & 0.02 & 0.04 & 0.002 & 0.086 & 0.098 \\
\hline $\mathrm{n}$ & 6 & 6 & 6 & 6 & 6 & 6 & 6 \\
\hline \multicolumn{8}{|c|}{ Consensus } \\
\hline & Cd & Co & $\mathbf{C u}$ & $\mathbf{F e}$ & & $\mathbf{N i}$ & $\mathbf{Z n}$ \\
\hline Mean & 1.016 & 46.5 & 2.33 & 0.69 & - & 8.79 & 7.59 \\
\hline$\pm \mathrm{SD}$ & 32 & 4.8 & 0.11 & 0.04 & - & 0.27 & 0.36 \\
\hline
\end{tabular}

Consensus values are obtained by the average of what the Geotraces community measured in samples divided among the members from a large bulk sample. SAFe consensus values were converted to molar units using a density of $1.025 \mathrm{~kg} / \mathrm{L}$

This article is protected by copyright. All rights reserved. 
Table 1b: Blank and Limit of detection concentrations in pM

\begin{tabular}{|c|c|c|c|c|c|}
\hline Element & Unit & Blank & \pm SD & $\mathrm{n}$ & $\begin{array}{c}\text { LOD } \\
(3 \mathrm{xSD})\end{array}$ \\
\hline $\mathrm{Cd}$ & $\mathrm{pM}$ & 0.41 & 2 & 20 & 8 \\
\hline $\mathrm{Co}$ & $\mathrm{pM}$ & 1.5 & 1 & 20 & 3 \\
\hline $\mathrm{Cu}$ & $\mathrm{pM}$ & 8.4 & 11 & 24 & 33 \\
\hline $\mathrm{Fe}$ & $\mathrm{pM}$ & 21.7 & 8 & 21 & 24 \\
\hline $\mathrm{Mn}$ & $\mathrm{pM}$ & 1.6 & 2.2 & 24 & 7 \\
\hline $\mathrm{Ni}$ & $\mathrm{pM}$ & 7.6 & 4.1 & 24 & 13 \\
\hline $\mathrm{Zn}$ & $\mathrm{pM}$ & 25 & 18 & 13 & 55 \\
\hline
\end{tabular}

Table 2: Endmember values used for the N/P-based four component mass-balance calculations. Numbers given in parentheses are the estimated uncertainties related to each endmember value. Analytical errors are all considerably smaller.

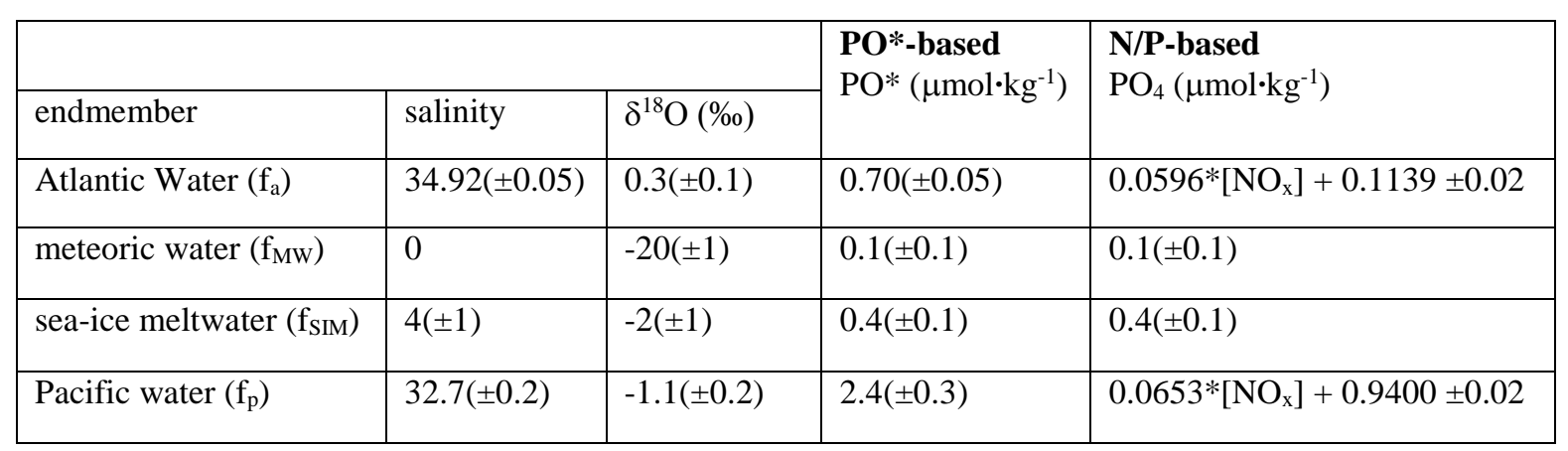

This article is protected by copyright. All rights reserved. 

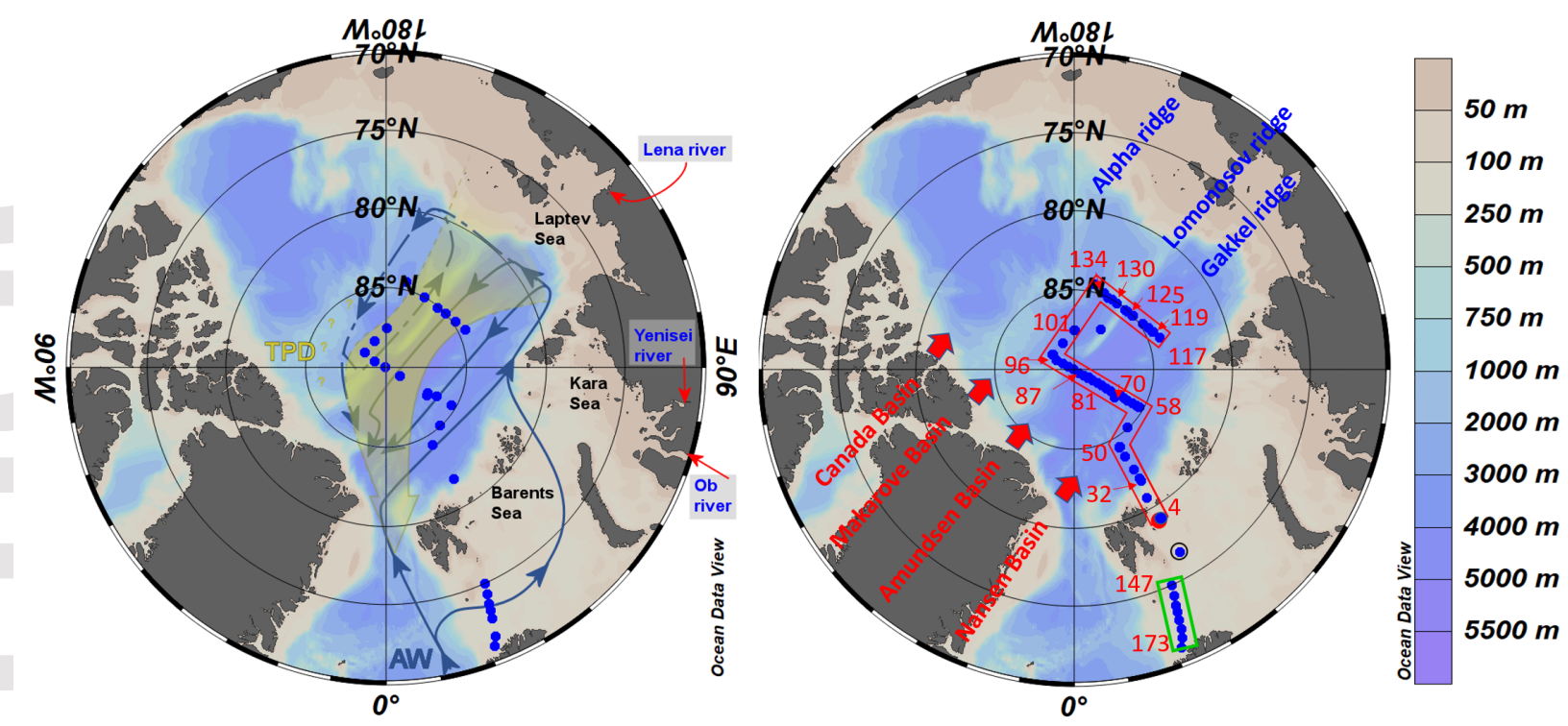

This article is protected by copyright. All rights reserved. 
A

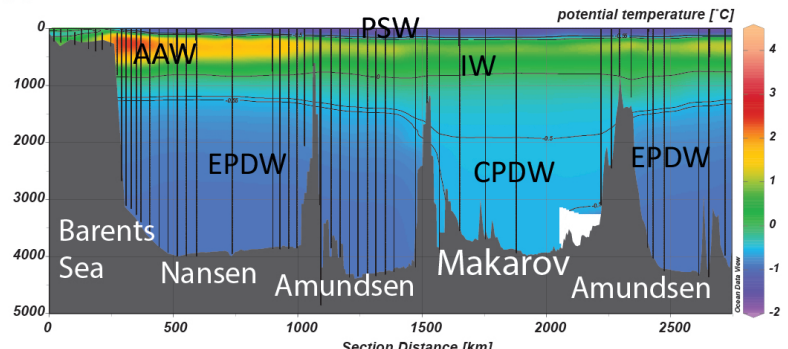

C Potential Temperature $\theta[$ degc]

E

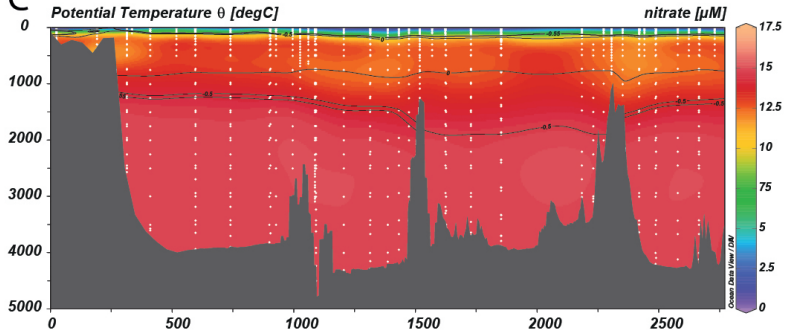

E Potential Temperature $\theta[$ degc]

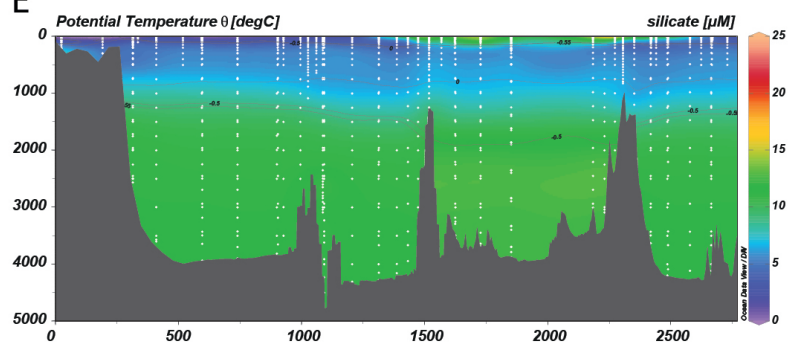

0
B

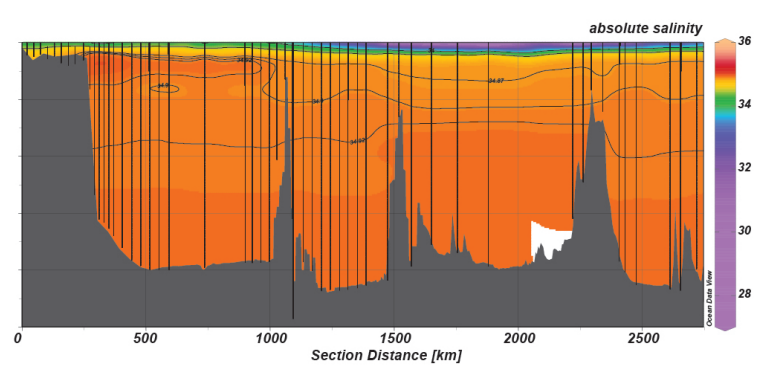

D Potential Temperature $\theta[\operatorname{deg} C]$

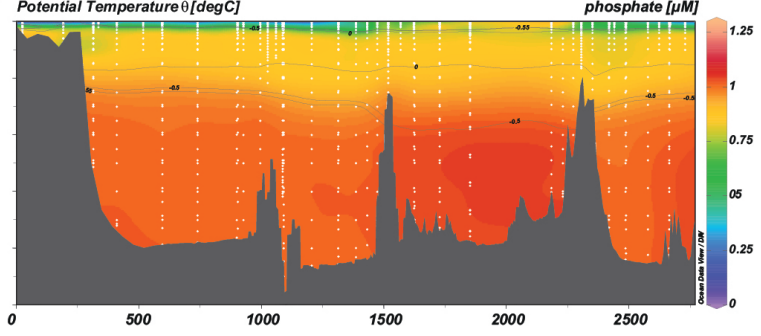



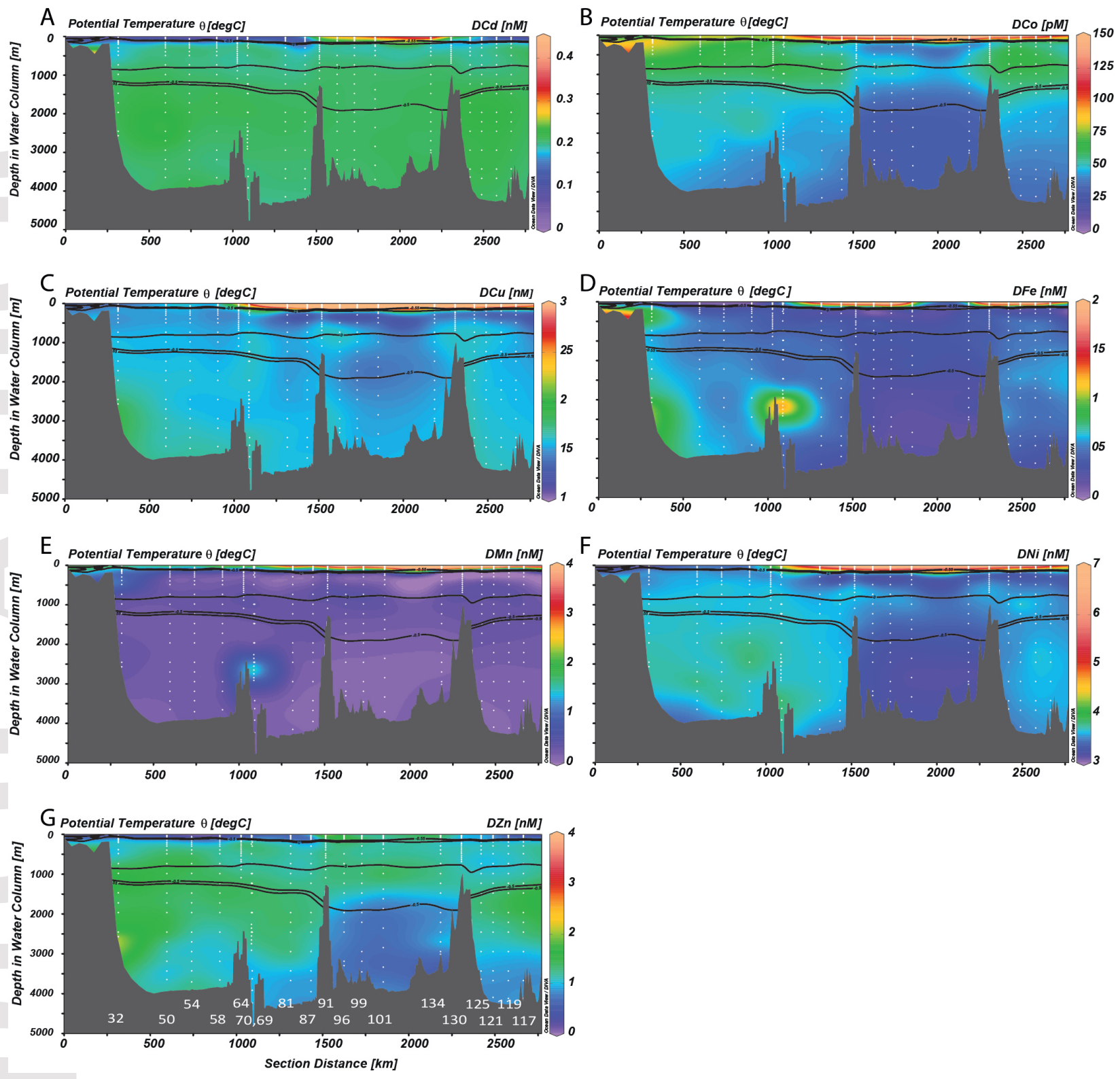

This article is protected by copyright. All rights reserved. 

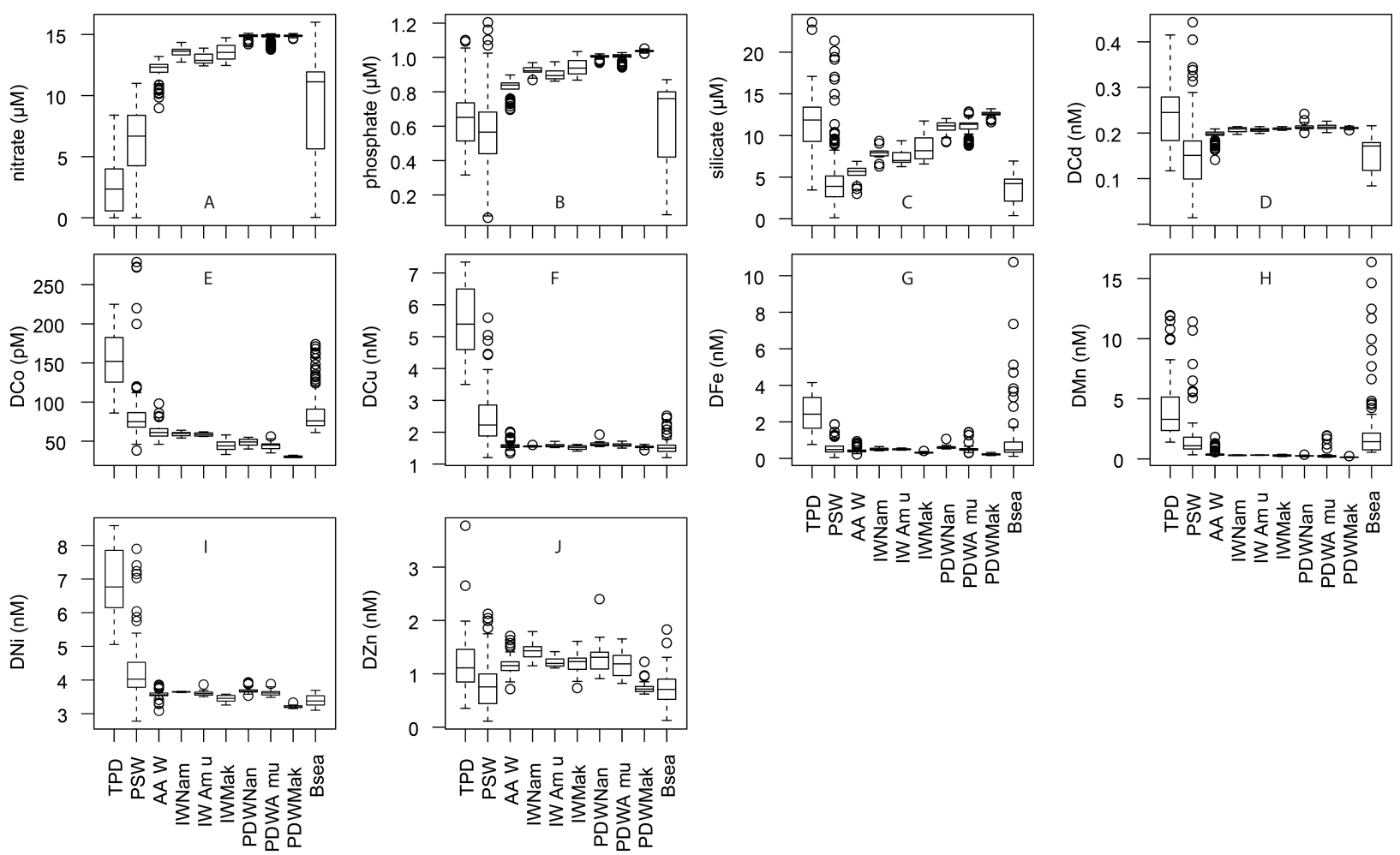

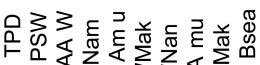

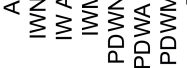

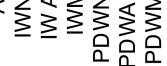

This article is protected by copyright. All rights reserved. 


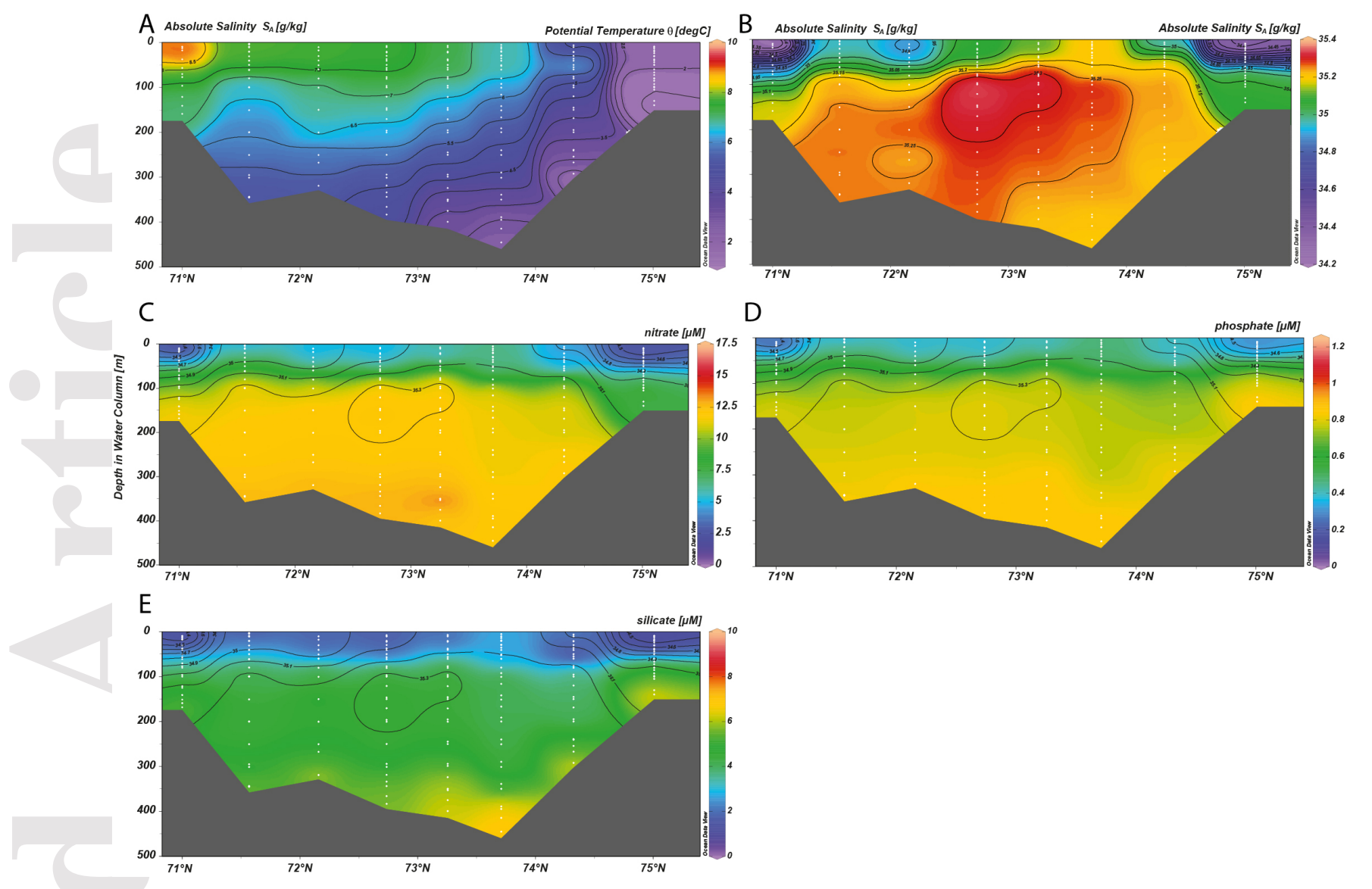

This article is protected by copyright. All rights reserved. 


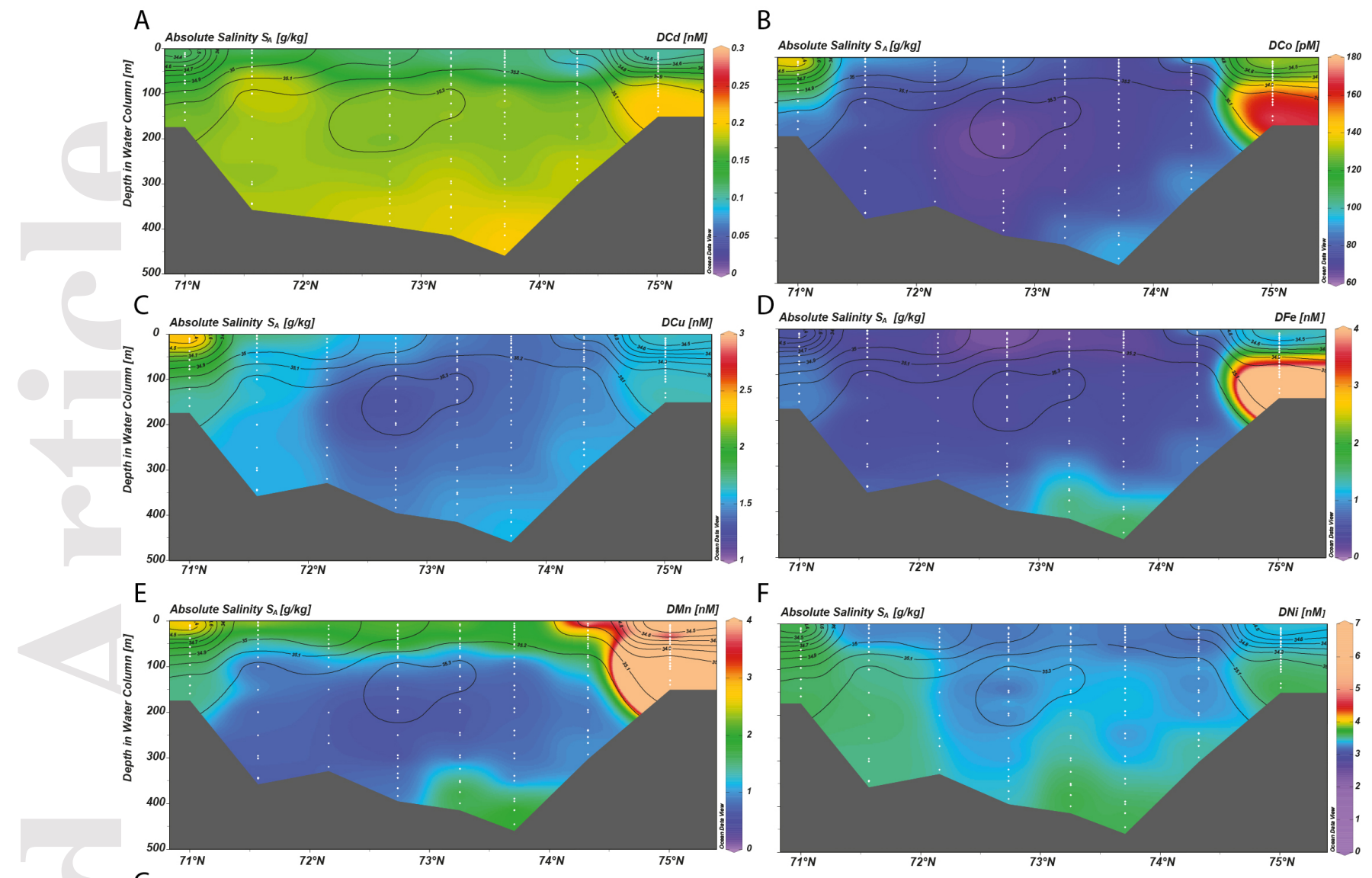

B

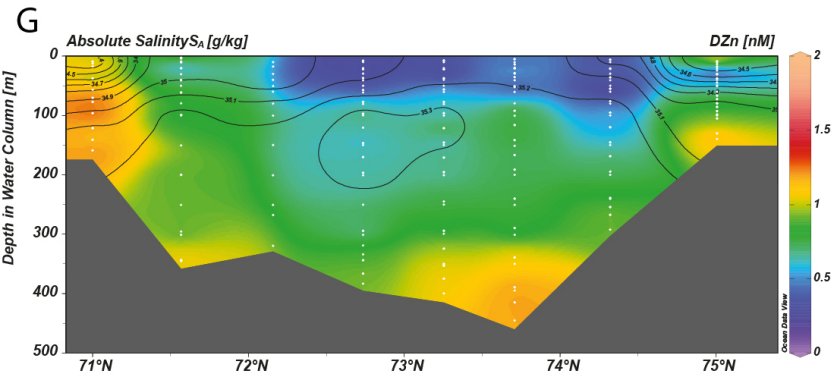

This article is protected by copyright. All rights reserved. 

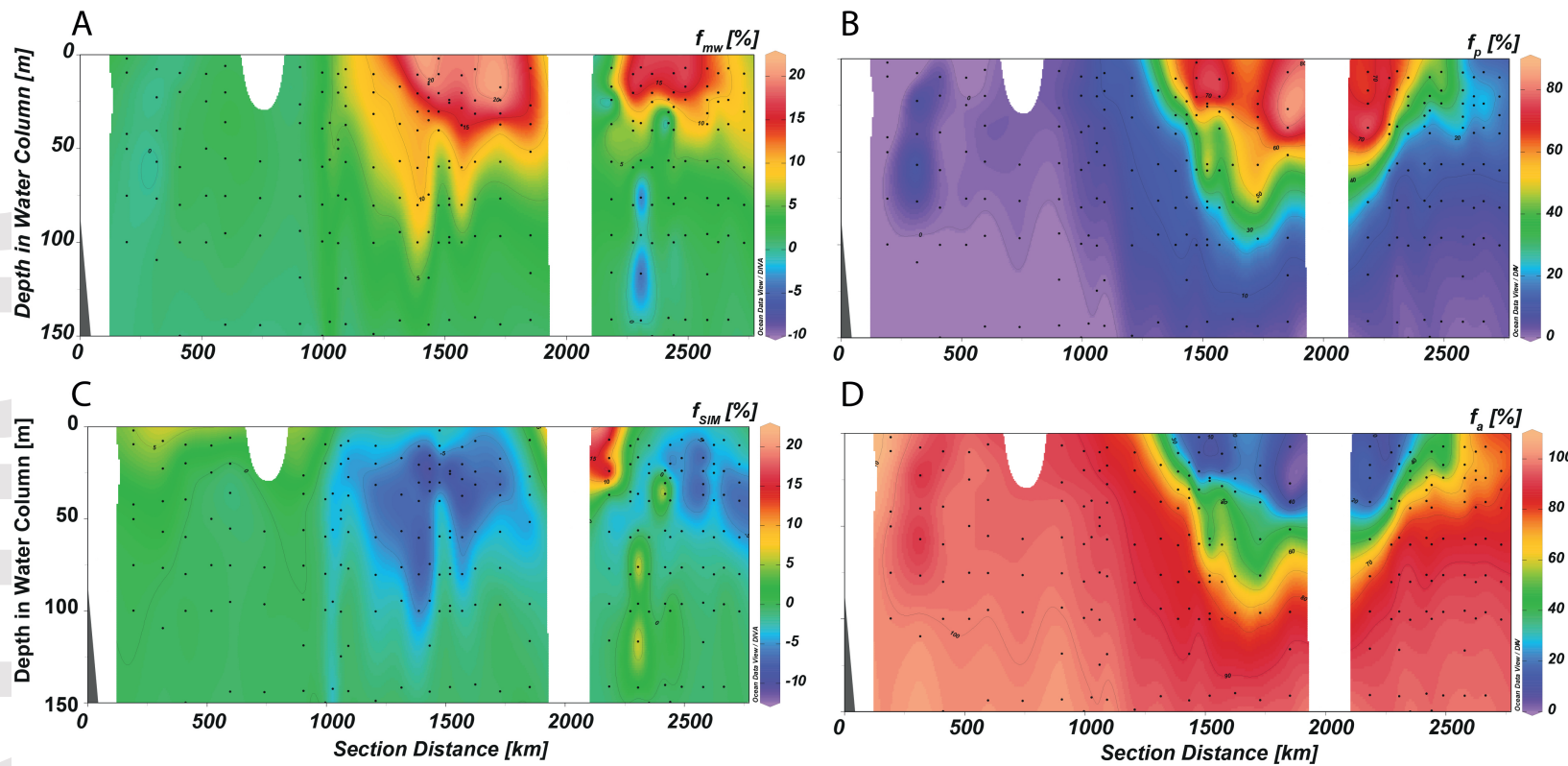

D
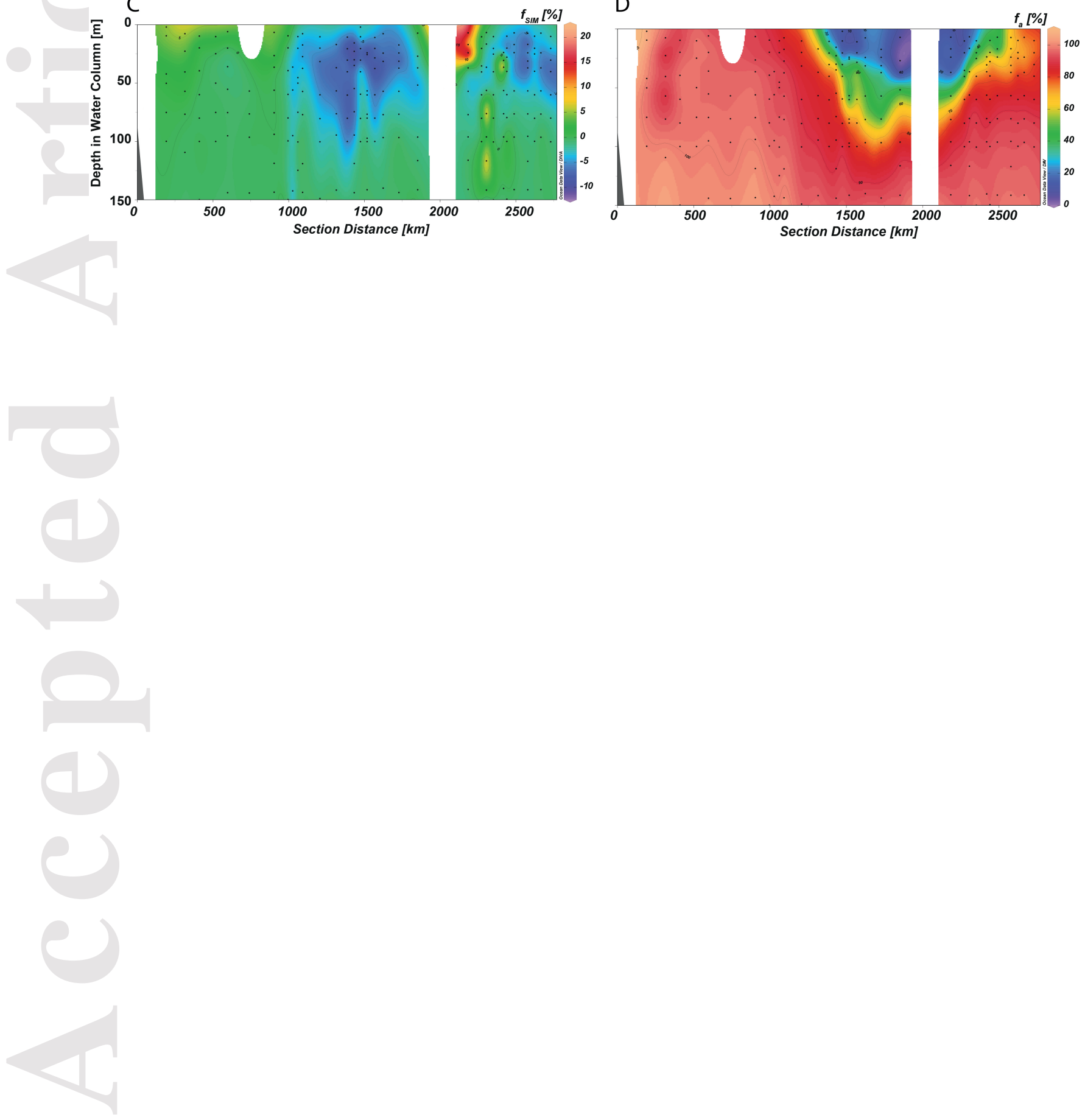

This article is protected by copyright. All rights reserved. 


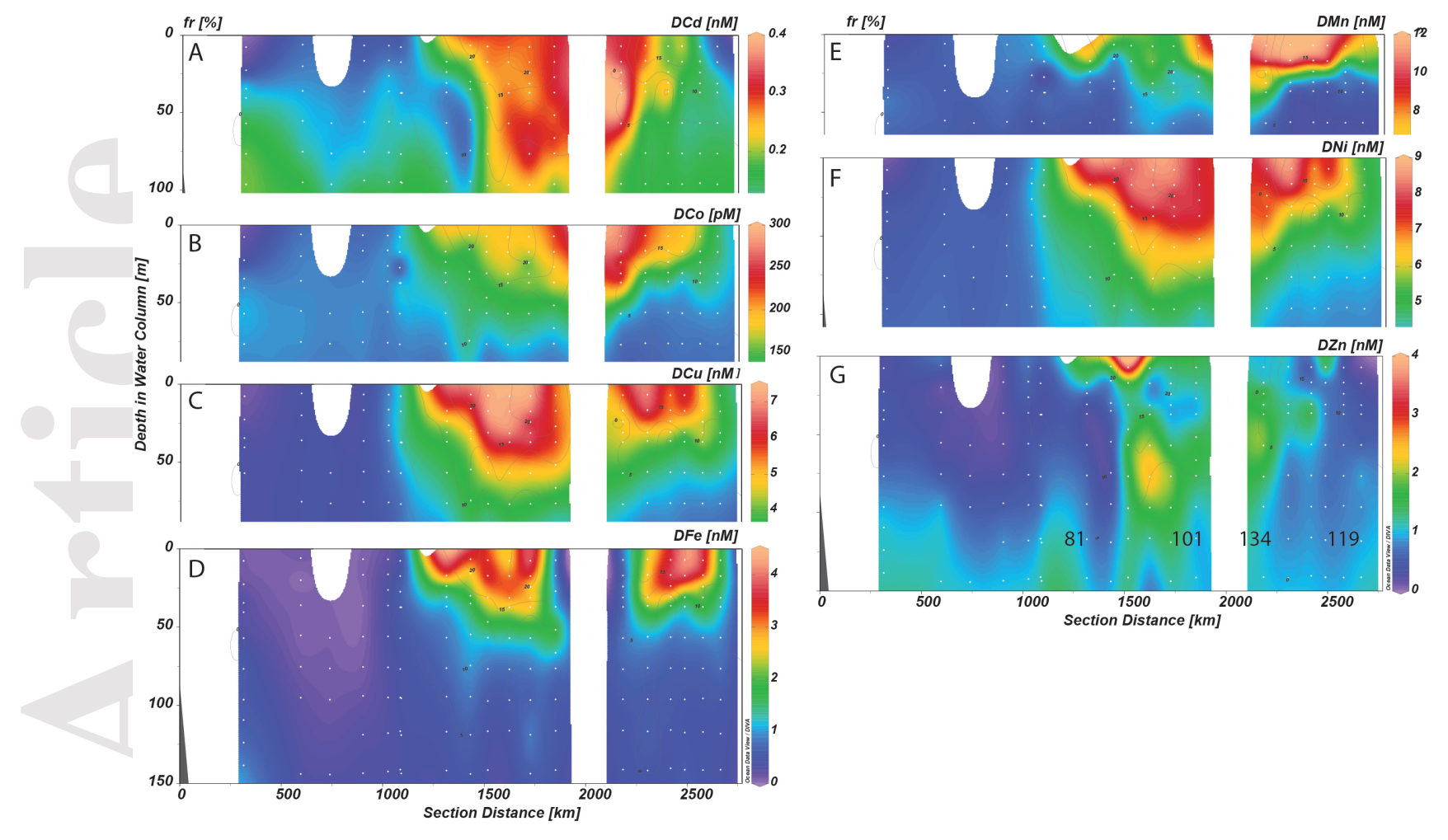

This article is protected by copyright. All rights reserved. 

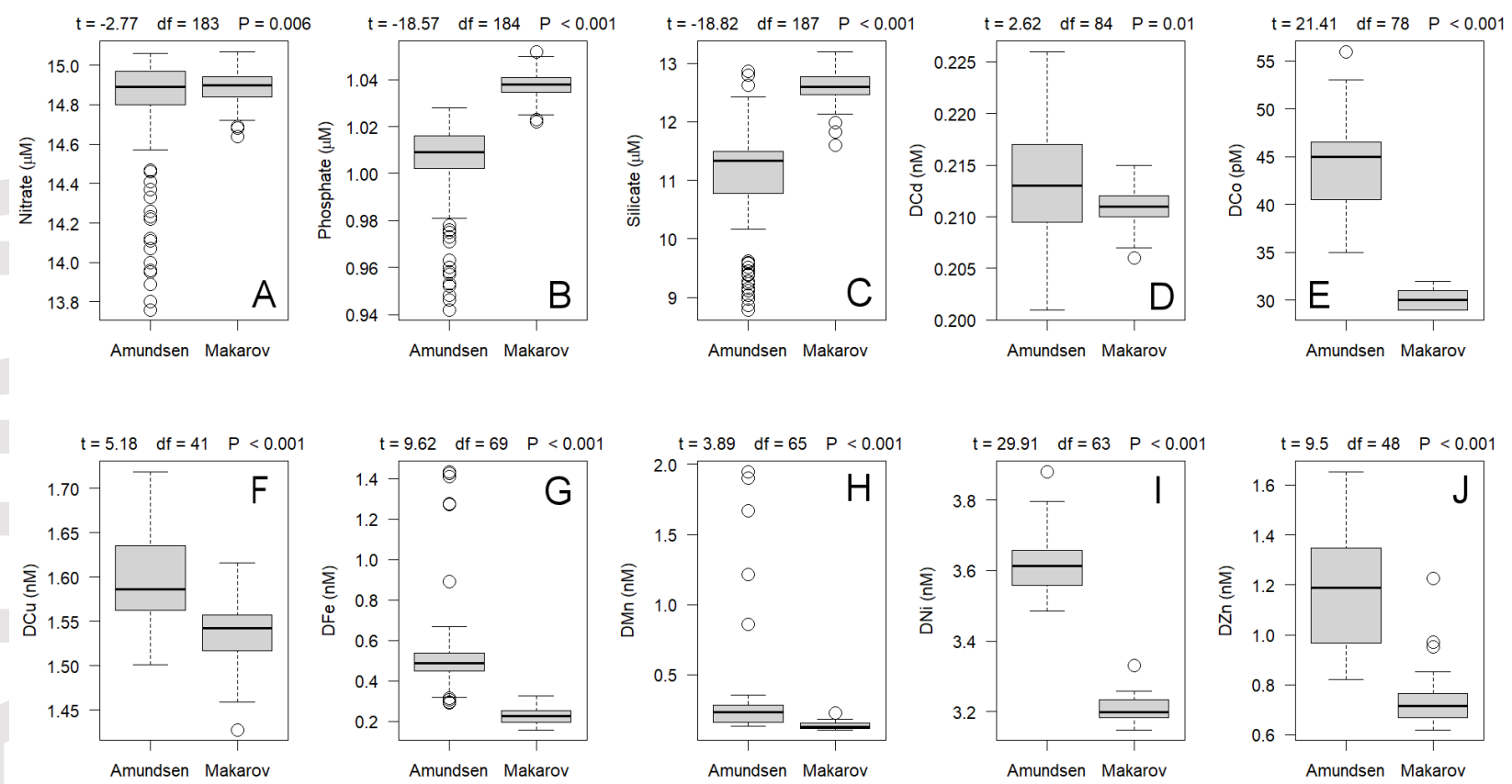

This article is protected by copyright. All rights reserved. 